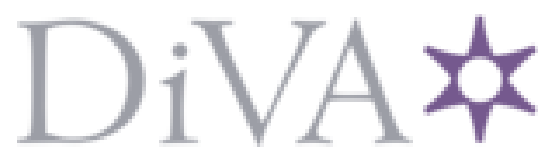

http://www.diva-portal.org

This is the published version of a paper published in Frontiers in Ecology and the Environment.

Citation for the original published paper (version of record):

Lehner, B., Reidy Liermann, C., Carmen, R., Vörösmarty, C., Fekete, B. et al. (2011)

High-resolution mapping of the world'sreservoirs and dams for sustainableriver-flow management.

Frontiers in Ecology and the Environment, 9(9): 494-502

http://dx.doi.org/10.1890/100125

Access to the published version may require subscription.

N.B. When citing this work, cite the original published paper.

Permanent link to this version:

http://urn.kb.se/resolve?urn=urn:nbn:se:umu:diva-49188 
High-resolution mapping of the world's reservoirs and dams for sustainable river-flow management

\author{
Bernhard Lehner $^{1 *}$, Catherine Reidy Liermann ${ }^{2}$ Carmen Revenga $^{3}$, Charles Vörösmarty ${ }^{4}$, Balazs Fekete ${ }^{4}$, \\ Philippe Crouzet $^{5}$, Petra Döll ${ }^{6}$, Marcel Endejan ${ }^{7}$, Karen Frenken ${ }^{8}$, Jun Magome ${ }^{9}$, Christer Nilsson ${ }^{10}$, \\ James C Robertson ${ }^{3}$, Raimund Rödel ${ }^{11}$, Nikolai Sindorf ${ }^{12}$, and Dominik Wisser ${ }^{13}$
}

Despite the recognized importance of reservoirs and dams, global datasets describing their characteristics and geographical distribution are largely incomplete. To enable advanced assessments of the role and effects of dams within the global river network and to support strategies for mitigating ecohydrological and socioeconomic costs, we introduce here the spatially explicit and hydrologically linked Global Reservoir and Dam database (GRanD). As of early 2011, GRanD contains information regarding 6862 dams and their associated reservoirs, with a total storage capacity of $6197 \mathrm{~km}^{3}$. On the basis of these records, we estimate that about 16.7 million reservoirs larger than $0.01 \mathrm{ha}$ - with a combined storage capacity of approximately $8070 \mathrm{~km}^{3}$ - may exist worldwide, increasing Earth's terrestrial surface water area by more than $305000 \mathrm{~km}^{2}$. We find that 575900 river kilometers, or $7.6 \%$ of the world's rivers with average flows above 1 cubic meter per second $\left(\mathrm{m}^{3} \mathrm{~s}^{-1}\right)$, are affected by a cumulative upstream reservoir capacity that exceeds $2 \%$ of their annual flow; the impact is highest for large rivers with average flows above $1000 \mathrm{~m}^{3} \mathrm{~s}^{-1}$, of which $46.7 \%$ are affected. Finally, a sensitivity analysis suggests that smaller reservoirs have substantial impacts on the spatial extent of flow alterations despite their minor role in total reservoir capacity.

Front Ecol Environ 2011; 9(9): 494-502, doi:10.1890/100125 (published online 31 May 2011)

$\mathrm{H}^{\mathrm{u}}$ umans have built dams and impoundments for thousands of years for various purposes, including flood control, water supply, irrigation, recreation, navigation, and the generation of hydropower (WCD 2000). Yet the number and storage volumes of dams and reservoirs have in-

\section{In a nutshell:}

- For thousands of years, reservoirs and dams have been built to benefit human society, and their numbers have increased markedly over the past 60 years

- Dams disrupt the ecological connectivity of rivers, whereas reservoirs' water storage and release patterns affect quantity, quality, and timing of downstream flows

- To assess related local and global impacts, scientists and managers require comprehensive and spatially explicit information about the location, size, and purpose of dams and reservoirs within the river network

- The Global Reservoir and Dam database (GRanD) will advance ecohydrological studies and assist sustainable flowmanagement strategies, such as the implementation of environmental flow standards or the prioritization of adaptive dam operations

${ }^{1}$ Department of Geography, McGill University, Montreal, Canada "(bernhard.lehner@mcgill.ca); ${ }^{2}$ University of Washington, Seattle, WA; ${ }^{3}$ The Nature Conservancy, Arlington, VA; ${ }^{4}$ The CUNY Environmental Cross-Roads Initiative, City University of New York, New York, NY; ${ }^{5}$ European Environment Agency, Copenhagen, Denmark; (continued on page 502) creased markedly over the past six decades, today reaching about 50000 large dams - defined as those higher than $15 \mathrm{~m}$ - in operation worldwide (Berga et al. 2006). These impoundments are estimated to have a cumulative storage capacity in the range of 7000 to $8300 \mathrm{~km}^{3}$ (Vörösmarty et al. 2003; Chao et al. 2008); this compares to the combined volumes of Lakes Michigan and Huron, or nearly $10 \%$ of the water stored in all natural freshwater lakes on Earth (Gleick 2000), and represents about one-sixth of the total annual river flow into the oceans (Hanasaki et al. 2006). Smaller impoundments are not taken into account in these estimates because there are no reliable global figures available. Extrapolations, however, suggest that many such impoundments exist (Downing et al. 2006; Wisser et al. 2010), including several million small dams in the US alone (Renwick et al. 2005).

Dams and reservoirs play an important role in the control and management of water resources. Undoubtedly, mitigating floods, securing water supplies, and providing hydropower have benefited human societies in many ways, allowing for improved human health, expanded food production, and economic growth. For example, large dams are estimated to contribute directly to $12-16 \%$ of global food production (WCD 2000). Recent projections suggest that 70\% more food will be needed by 2050 (nearly 100\% in developing countries) to cope with a $40 \%$ increase in world population and to accommodate expected shifts in global dietary patterns (Bruinsma 2009); part of that additional food will be produced on irrigated lands that will 
require $11 \%$ more water, much of it likely to come from storage reservoirs. Additionally, hydropower provides about $19 \%$ of the world's electricity supply and is used in more than 150 countries (WCD 2000).

On the other hand, dams and reservoirs, especially large ones, can induce substantial costs to human societies, exemplified by displacement/resettlement, social disruption, changes in water and food security, and increased incidence of communicable diseases (Scudder 2006). In terms of environmental effects, flow regulation is considered one of the main adverse ecological consequences of dams and reservoirs (Poff et al. 1997; Bunn and Arthington 2002). The goal of many dam operations is to eliminate peak flows, to stabilize low flows, or to impound or divert river flows partially or entirely. These alterations lead to numerous physical and ecological impacts on freshwater, terrestrial, and marine ecosystems and their dependent species (Pringle et al. 2000; Dudgeon et al. 2006; Freeman and Marcinek 2006; Carlisle et al. 2011).

Many riverine species are adapted to, and synchronized with, specific river flow patterns, such as spring peak floods or summer low flows. These patterns cue species to reproduce, disperse, migrate, feed, and avoid predators; alterations to natural flow patterns may disrupt life cycles and ecological processes. To mitigate negative effects, ecologists and water resource planners are increasingly interested in the adaptation of dam operations toward releasing "environmental flows" (ie an appropriate "quantity, quality, and timing of water flows required to sustain freshwater and estuarine ecosystems and the human livelihoods and well-being that depend on these ecosystems"; Brisbane Declaration 2007). In particular, given that the downstream effects of flow alterations can be far reaching, the ELOHA framework (Ecological Limits of Hydrologic Alteration; Poff et al. 2010) explicitly calls for regional-scale hydrologic modeling and analyses to inform environmental flow management, when lack of time and resources preclude evaluating individual rivers and locations.

Beyond flow regulation, dams also fragment aquatic habitats (Jansson et al. 2000; Nilsson et al. 2005), impeding not only the movement of species but also the delivery of nutrients and sediments downstream. By decreasing sediment transport, dams reduce the riverine habitat-forming substrate available for critical life stages, such as fish nesting and refuge (Černý et al. 2003). Reduced sediment and nutrient transport also affects estuarine and coastal communities (Syvitski et al. 2005; Baisre and Arboleya 2006; Ericson et al. 2006). Many river deltas, for instance, are sinking as a result of reduced sediment delivery, thereby increasing the vulnerability of human populations depending on their ecosystem services for survival (Syvitski et al. 2009). Furthermore, flood attenuation reduces the rich productivity of natural floodplains (Arthington and Welcomme 1995; Tockner et al. 2008), putting at risk millions of people relying on them for their livelihoods (Richter et al. 2010). Similar to that of sediments, the distribution, trapping, or accumulation of contaminants in river systems is modified by dam obstruction and reservoir retention.
Shiklomanov (2000) has estimated that the additional water lost as a result of reservoir-based evaporation amounts to about $5 \%$ of total global river flows, thus exceeding industrial and domestic water consumption combined, which can greatly contribute to diminishing water resources in some regions. Also, the increased water storage in the world's reservoirs may collectively be responsible for a measurable delay in sea-level rise (Chao et al. 2008); hence, detailed knowledge of the global extent of reservoirs over time is important for improving climate-change-related risk assessments. Smaller reservoirs are increasingly of concern to researchers because their cumulative effects may be considerable, yet they have so far remained underemphasized and unexamined (Downing et al. 2006). For example, Harrison et al. (2009) showed that small reservoirs play an important regional and global role in the removal of nitrogen from surface water. Finally, although hydropower is often perceived and promoted as "green" energy, reservoirs are estimated to be responsible for at least $4 \%$ of human-induced global warming in the form of greenhouse-gas emissions (eg methane; St Louis et al. 2000; Lima et al. 2008). In a recent study, Del Sontro et al. (2010) found that temperate reservoirs, under certain circumstances, may have higher methane emission rates than expected, especially in a warming climate; they concluded that a more detailed analysis of the biogeochemical and geographical setting of reservoirs is needed.

Given these concerns, there is widespread agreement in the ongoing sustainable dam management/planning debate about the importance of better assessing the role and effects of dams and reservoirs (eg WCD 2000) and of minimizing associated societal and environmental costs while leveraging the benefits. Scientific research is recognized to provide critical input to this debate but, unfortunately, inadequate data and assessment tools - particularly at regional and global scales - have previously hindered the advancement of new and rigorous studies.

In this paper, we offer three contributions to promote this dialogue. First, we introduce a new global dam and reservoir database, at unprecedented spatial resolution, to serve as the backbone for a suite of new assessments. Second, by conducting extrapolations from this database, we provide robust estimates of the number and storage capacities of small reservoirs worldwide, which can inform subsequent ecological assessments. Third, by using the database in a pilot study to demonstrate its capability, we present spatially detailed calculations of the degree of flow regulation caused by dams. As a result, we create a first-time global risk map of potential impacts of reservoir clusters on downstream flow regimes at the resolution of individual river reaches.

\section{A new global reservoir and dam database}

Despite the many critical environmental and social tradeoffs associated with dams and reservoirs, global datasets 


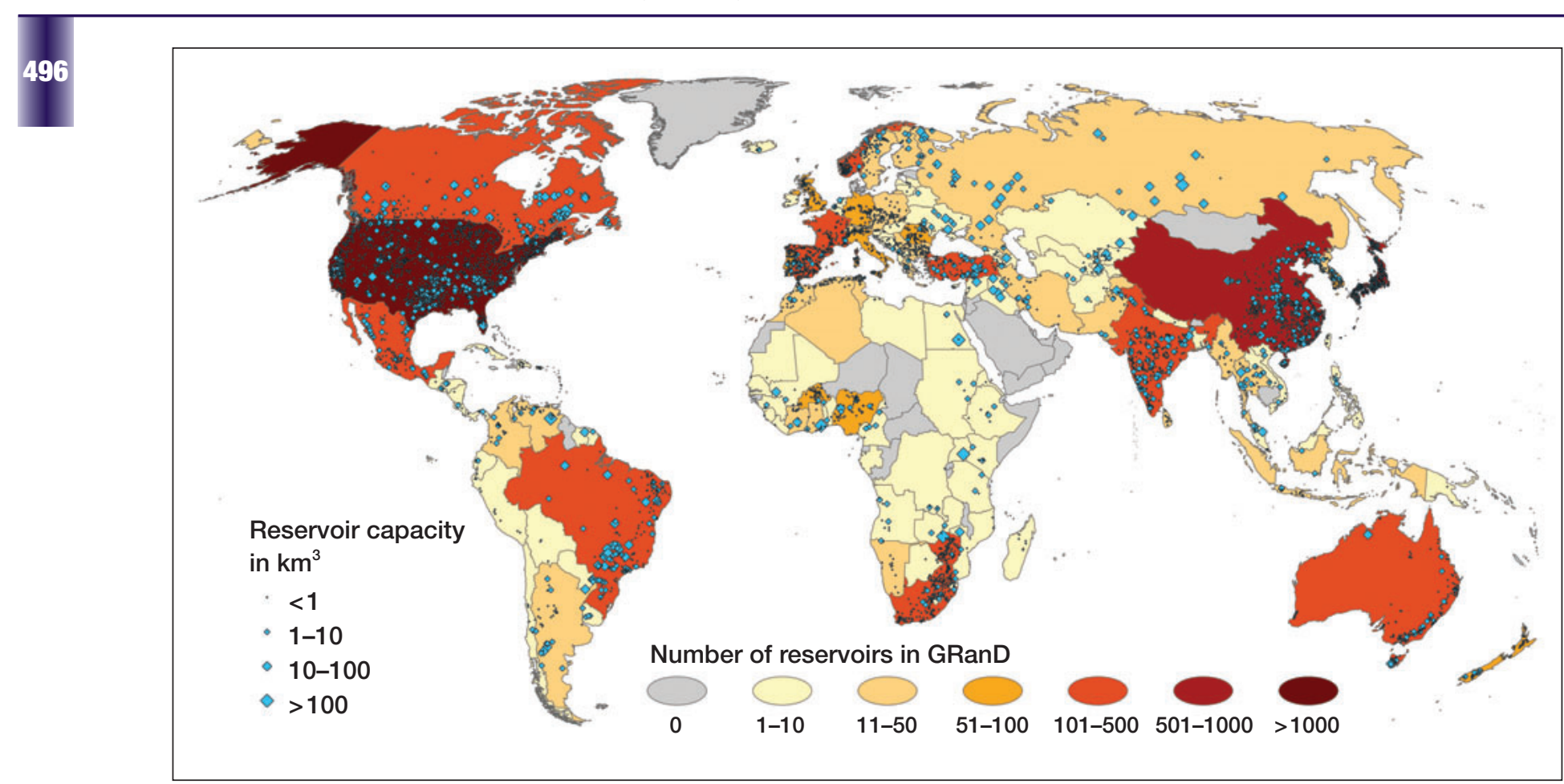

Figure 1. Global distribution (by country) of large reservoirs included in GRanD.

describing their characteristics and geographical distribution have heretofore been largely incomplete (see WebPanel 1 and WebTable 1). To address this shortcoming, the Global Water System Project, a collaborative project of the Earth System Science Partnership, initiated an international effort to collate existing dam and reservoir datasets, with the aim of providing a single, geographically explicit and reliable database for the scientific community: the Global Reservoir and Dam database (GRanD). For technical details of the data development, see WebPanel 1.

The current version 1.1 of GRanD contains 6862 records of reservoirs and their associated dams (Figure 1), with a cumulative storage capacity of $6197 \mathrm{~km}^{3}$. The largest combined volumes are concentrated in Canada, Russia, the US, Brazil, and China (WebTable 2). GRanD's attribute data include (in most cases) the dam and reservoir names, spatial coordinates, construction year, surface area, storage capacity, dam height, main purpose, and elevation. Up - and downstream topology was introduced by linking GRanD to HydroSHEDS, a nearglobal, high-resolution digital river network (Lehner et al. 2008). This linkage allowed for the derivation of additional attributes, such as the contributing catchment area for each reservoir, and estimates of the long-term average discharge at all reservoir locations.

\section{Estimating the amount and volume of smaller reservoirs}

The global distribution of natural lakes and their surface areas can be described by a power law distribution (Lehner and Döll 2004), and a similar Pareto distribution has been proposed for artificial reservoirs (Downing et al. 2006). By fitting such a statistical distribution to the GRanD data (WebPanel 2 and WebFigure 1), we extrapolated the number, total surface area, and volume of smaller reservoirs. Table 1 indicates good overall correspondence between GRanD and the Pareto model in the reservoir size classes $10 \mathrm{~km}^{2}$ to $10000 \mathrm{~km}^{2}$. For the calculation of total global numbers, we combined GRanD data for reservoirs larger than $10 \mathrm{~km}^{2}$ with the values derived from the Pareto model for smaller reservoirs.

We estimate that there are about 2.8 million impoundments larger than 0.1 ha $\left(0.001 \mathrm{~km}^{2}\right)$ worldwide, and 16.7 million when including those larger than 0.01 ha (100 $\mathrm{m}^{2}$; Table 1). The total storage volume of all reservoirs amounts to $8069 \mathrm{~km}^{3}$ and their combined area covers 305 $723 \mathrm{~km}^{2}$ (excluding regulated natural lakes), equivalent to an increase of Earth's naturally occurring terrestrial water surface by $7.3 \%$ (Downing et al. 2006).

Previous estimates of the numbers, surface areas, and/or storage capacities of large and small reservoirs differed considerably among published studies (eg St Louis et al. 2000; Lehner and Döll 2004; Downing et al. 2006; Wisser et al. 2010), some indicating a substantially higher surface extent than ours (up to fivefold). Yet by distinguishing between human-made reservoirs and (albeit currently limited to only very large) regulated natural lakes, GRanD enables a more robust analysis for estimating total reservoir area. Thus we believe that previous approximations, by not accounting for such a distinction, may have generated overestimates. Furthermore, our results align reasonably well with those of Downing et al. (2006) - which show slightly higher numbers of very small reservoirs - and also agree with the total surface area recorded in the World Register of Dams ( $400000 \mathrm{~km}^{2}$, including regulated nat- 
ural lakes; ICOLD 1998-2009). Because the reservoir volume follows a saturating function, the total global storage volume is mostly determined by large reservoirs. This observation fits well with previous studies (Vörösmarty et al. 2003), and the results indicate that GRanD captures more than $75 \%$ of the total global storage capacity.

\section{Quantifying the global degree of river regulation}

The proportion of a river's annual flow that can be withheld by a reservoir or cluster of reservoirs can serve as a first-level approximation of the potential impact on downstream flows. This index, which - following other authors - we term "degree of regulation" (DOR), has in one form or another been a key component of seminal studies on flow regulation (eg Nilsson et al. 2005) or has been analyzed in terms of the hydrologically equivalent "change in residence time" or "water aging" (eg Vörösmarty et al. 1997). However, these studies were limited in scale and extent - typically providing single values for only the world's largest river basins - because of poor data availability for dams, reservoirs, and global river hydrography. Building on these efforts, we present advanced and spatially detailed calculations of DOR by coupling GRanD with the global HydroSHEDS river network (Lehner et al. 2008).

A high DOR value indicates an increased probability that substantial discharge volumes can be stored throughout a given year and released at later times. Both temporal storage and delayed release alter the natural flow regime and, as a result of the increased stagnation and stratification of the stored water, can also affect other characteristics, such as water temperature, dissolved oxy- gen content, or suspended sediment load. In particular, multi-year reservoirs (DOR > 100\%) have the ability to release water in accordance with an artificial, demanddriven regime, often with the explicit goal to supply water in contrast to natural expectations, such as by increasing dry-season flows or eliminating flood peaks. Among the largest 100 reservoirs in GRanD, 27 showed individual DOR ratios above $200 \%$, including the Hoover Dam in the US (284\%) and the African Akosombo and Kariba dams (each exceeding 300\%). Although smaller DOR ratios may imply less of a general impact, some critical aspects of the flow regime may still be severely altered. For example, China's Three Gorges Dam can store only $4.5 \%$ of the total annual flow of the Yangtze River, but its design purpose is to eliminate smaller floods and to reduce extreme events, and it has substantially altered the downstream sediment transport of the Yangtze (Xu and Milliman 2009). Dynesius and Nilsson (1994) used a DOR threshold of 2\% - equivalent to the capacity of storing about one week of the total annual flow - to distinguish between free-flowing rivers and the onset of ecological consequences. In the same sense, here we refer to rivers with a DOR $\geq 2 \%$ as "affected" rivers, yet we provide additional results for a suite of higher DOR thresholds in order to support a more differentiated interpretation. For details of our DOR calculations, see WebPanel 3.

Global statistics and maps of the affected river network are provided in Table 2 and Figures 2 and 3. Obviously, higher DOR thresholds lead to smaller absolute extents of affected river reaches. Independently from the threshold, however, the relative impact increases with river size, peaking at large rivers $\left(1000 \mathrm{~m}^{3} \mathrm{~s}^{-1}\right.$ to $10000 \mathrm{~m}^{3} \mathrm{~s}^{-1}$; Table

Table 1. Estimation of the global number of reservoirs, representative mean areas per size class, total areas, and reservoir volumes, as compiled in GRanD and as derived from the Pareto distribution model (see WebPanel 2), grouped by reservoir size classes

\begin{tabular}{|c|c|c|c|c|c|c|c|c|c|}
\hline \multirow{2}{*}{\multicolumn{2}{|c|}{$\begin{array}{l}\text { Reservoir surface } \\
\text { area }\left(\mathrm{km}^{2}\right)\end{array}$}} & \multicolumn{4}{|c|}{ GRanD } & \multicolumn{4}{|c|}{ Pareto model } \\
\hline & & Number ${ }^{a}$ & $\begin{array}{c}\text { Avg area } \\
\left(\mathrm{km}^{2}\right)\end{array}$ & $\begin{array}{l}\text { Total area } \\
\left(10^{3} \mathrm{~km}^{2}\right)\end{array}$ & $\begin{array}{l}\text { Volume } \\
\left(\mathrm{km}^{3}\right)\end{array}$ & Number & $\begin{array}{l}\text { Avg area } \\
\left(\mathrm{km}^{2}\right)\end{array}$ & $\begin{array}{l}\text { Total area } \\
\left(10^{3} \mathrm{~km}^{2}\right)\end{array}$ & $\begin{array}{c}\text { Volume } \\
\left(\mathrm{km}^{3}\right)\end{array}$ \\
\hline 0.0001 & 0.001 & & & & & 13951674 & 0.000280 & 3.9 & 169.5 \\
\hline 0.001 & 0.01 & & & & & 2311673 & 0.00280 & 6.5 & 254.8 \\
\hline 0.01 & 0.1 & & & & & 383024 & 0.0280 & 10.7 & 383.1 \\
\hline 0.1 & I & 1275 & 0.48 & 0.6 & 35.6 & 63464 & 0.280 & 17.8 & 575.9 \\
\hline 1 & 10 & 3472 & 3.8 & 13.2 & 297.2 & 10515 & 2.80 & 29.5 & 865.9 \\
\hline 10 & 100 & 1683 & 30.1 & 50.7 & 1194.6 & 1742 & 28.0 & 48.8 & 1301.9 \\
\hline 100 & 1000 & 348 & 278.0 & 96.7 & 1941.6 & 289 & 280.3 & 80.9 & 1957.5 \\
\hline 1000 & 10000 & 59 & 2497.3 & 147.3 & 2371.4 & 48 & 2803.0 & 134.1 & 2942.9 \\
\hline 10000 & 100000 & 4 & 35973.4 & 143.9 & 312.6 & 8 & 28030.3 & 222.2 & 4424.6 \\
\hline
\end{tabular}

Total number of reservoirs: I6.7 million
Total storage volume: $8069.3 \mathrm{~km}^{3}$

Notes: Global totals are calculated as the sum of values from GRanD for reservoirs larger than $10 \mathrm{~km}^{2}$ and from the Pareto model for reservoirs smaller than $10 \mathrm{~km}{ }^{2}$. Other values are provided for comparison. ${ }^{\mathrm{a}} \mathrm{A}$ few $\mathrm{GRanD}$ reservoirs were not included in the list because of inadequate information on area or volume. ${ }^{\mathrm{b}}$ The total reservoir area in GRanD includes regulated natural lakes (such as Lakes Victoria, Baikal, and Ontario). 'The total "added" reservoir area excludes regulated natural lakes (as indicated in GRanD). 


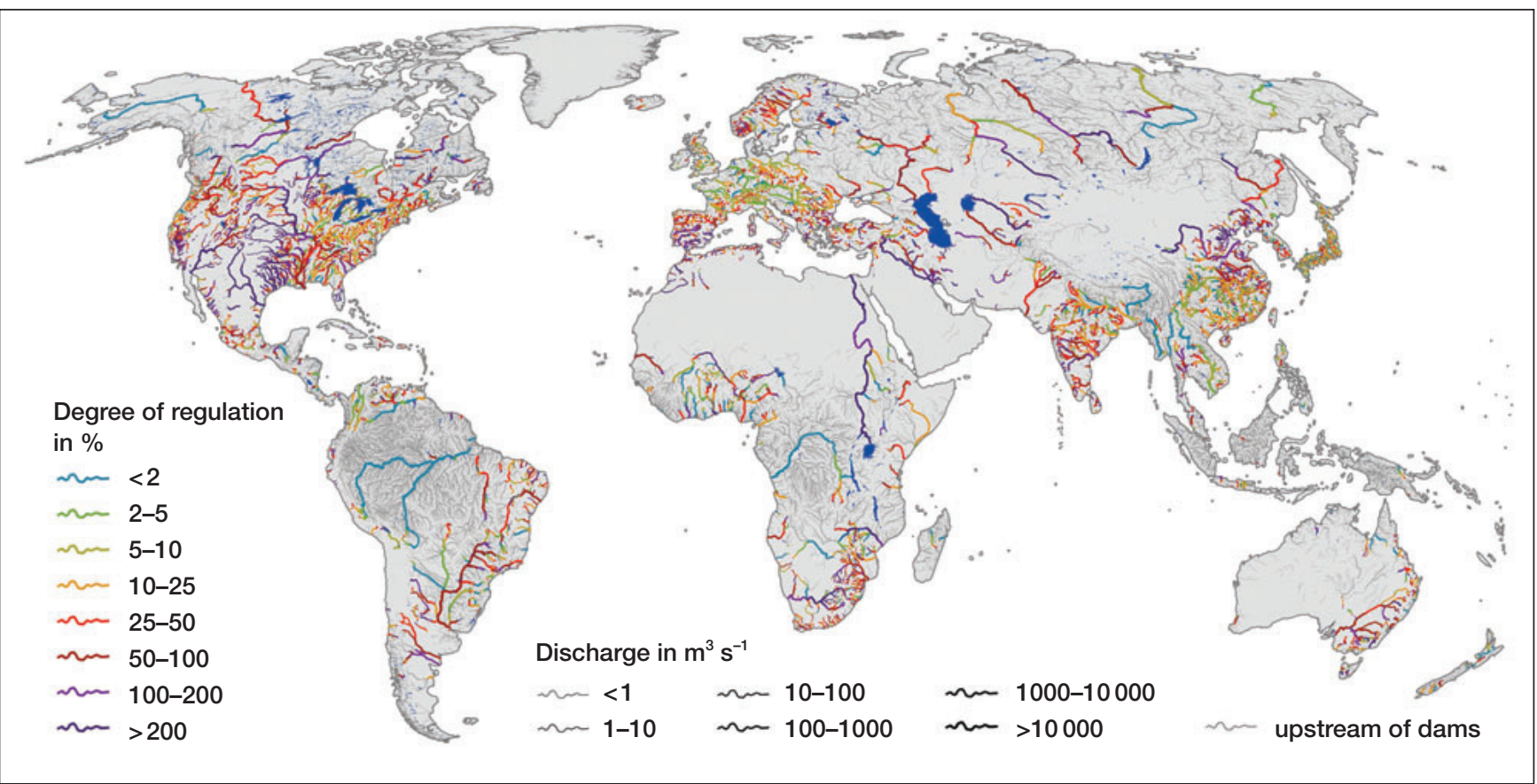

Figure 2. Affected river reaches downstream of GRanD reservoirs. Different colors show an increasing degree of regulation, whereas line width is proportional to average long-term discharge. Rivers in gray have no large dams upstream.

2 and Figure 3). Very large rivers show slightly reduced levels again, most likely because massive flows, such as those of the Amazon or Congo rivers, cannot easily be impounded in their entirety. When adopting a DOR threshold of $2 \%$, we find that 575900 river kilometers, or $7.6 \%$ of the world's rivers with average flows exceeding $1 \mathrm{~m}^{3} \mathrm{~s}^{-1}$, are affected by upstream reservoirs. Of these, $84300 \mathrm{~km}$ are large rivers with average flows of more than $1000 \mathrm{~m}^{3} \mathrm{~s}^{-1}$, representing $46.7 \%$ of all rivers in this size class globally. Approximately $117500 \mathrm{~km}$, or 2.3\% of small rivers with average flows below $10 \mathrm{~m}^{3} \mathrm{~s}^{-1}$, are affected. In total, 139200 river kilometers have enough cumulative reservoir capacity in their respective upstream catchment to store more than the entire annual river flow (DOR $\geq 100 \%$; Table 2 ).

Several basins and countries stand out as being highly affected over large areas (for a regional breakdown of results, see Table 3, WebTable 2, and WebFigures 2-8),

\begin{tabular}{|c|c|c|c|c|c|c|c|c|c|}
\hline \multirow{2}{*}{$\begin{array}{c}\text { River size } \\
\text { (average flow } \\
\text { in } \mathrm{m}^{3} \mathrm{~s}^{-1} \text { ) }\end{array}$} & \multirow{2}{*}{$\begin{array}{l}\text { Length of all } \\
\quad \text { rivers } \\
\text { (in } 10^{3} \mathrm{~km} \text { ) }\end{array}$} & \multicolumn{7}{|c|}{ Global extent of affected rivers downstream of GRanD reservoirs } & \multirow[b]{2}{*}{ Units } \\
\hline & & $\operatorname{DOR}(\%) \geq 2$ & $\geq 5$ & $\geq 10$ & $\geq 25$ & $\geq 50$ & $\geq 100$ & $\geq 200$ & \\
\hline \multirow{2}{*}{$\begin{array}{l}\text { Small } \\
(1-10)\end{array}$} & \multirow{2}{*}{5081.9} & 117.5 & 113.7 & 105.0 & 85.8 & 65.0 & 42.5 & 24.6 & $10^{3} \mathrm{~km}$ \\
\hline & & 2.3 & 2.2 & 2.1 & 1.7 & 1.3 & 0.8 & 0.5 & $\%$ \\
\hline \multirow{2}{*}{$\begin{array}{l}\text { Small-medium } \\
(10-100)\end{array}$} & \multirow{2}{*}{1696.6} & 203.3 & 181.7 & 158.0 & 115.4 & 78.8 & 44.8 & 21.6 & $10^{3} \mathrm{~km}$ \\
\hline & & 12.0 & 10.7 & 9.3 & 6.8 & 4.6 & 2.6 & 1.3 & $\%$ \\
\hline \multirow{2}{*}{$\begin{array}{l}\text { Medium } \\
(100-1000)\end{array}$} & \multirow{2}{*}{603.2} & 170.8 & 152.0 & 133.0 & 100.0 & 69.0 & 36.4 & 15.8 & $10^{3} \mathrm{~km}$ \\
\hline & & 28.3 & 25.2 & 22.0 & 16.6 & 11.4 & 6.0 & 2.6 & $\%$ \\
\hline \multirow{2}{*}{$\begin{array}{l}\text { Large } \\
(1000-10000)\end{array}$} & \multirow{2}{*}{155.7} & 73.0 & 64.2 & 56.2 & 43.0 & 30.3 & 15.3 & 7.0 & $10^{3} \mathrm{~km}$ \\
\hline & & 46.9 & 41.3 & 36.1 & 27.6 & 19.5 & 9.8 & 4.5 & $\%$ \\
\hline \multirow{2}{*}{$\begin{array}{l}\text { Very large } \\
(>10000)\end{array}$} & \multirow{2}{*}{25.0} & 11.3 & 10.7 & 8.5 & 5.1 & 4.1 & 0.2 & 0.0 & $10^{3} \mathrm{~km}$ \\
\hline & & 45.1 & 42.8 & 34.0 & 20.3 & 16.2 & 0.9 & 0.0 & $\%$ \\
\hline \multirow[t]{2}{*}{ Total } & 7562.4 & 575.9 & 522.4 & 460.7 & 349.4 & 247.3 & 139.2 & 69.0 & $10^{3} \mathrm{~km}$ \\
\hline & & 7.6 & 6.9 & 6.1 & 4.6 & 3.3 & 1.8 & 0.9 & $\%$ \\
\hline
\end{tabular}

Notes: DOR is the cumulative upstream storage in percent of average flow. All length estimates were calculated from the HydroSHEDS river network at 15 arc-second resolution (Lehner et al. 2008). 
with many impacted tributaries resulting from a multitude of dispersed dams, such as those of the MississippiMissouri Basin in North America or in parts of Europe and Asia, including India and China. In other basins, such as the Parana-Paraguay in South America, effects are concentrated to certain sub-basins. Singular dams can have the potential for abrupt but severe alterations in the DOR ratio, and the effects can propagate far downstream on the main-stem river, as is apparent in the Nile, Senegal, or Zambezi basins of Africa. Overall, our results - albeit at much higher spatial resolution - agree with previous findings indicating that reservoirs intercept more than $40 \%$ of global river discharge (Vörösmarty et al. 2003), and that more than $50 \%$ of large river systems are affected by dams (Nilsson et al. 2005).

\section{Uncertainties and sensitivity analysis}

The results of our DOR study need careful interpretation to avoid arriving at misleading global generalizations. First, the impacts and consequences of flow regulation may vary for different river size classes. Large rivers are more likely to be of high regional or international importance, including far-reaching ecological and socioeconomic aspects, and strong dependencies between agricultural practices, fisheries, and natural river flows may exist.

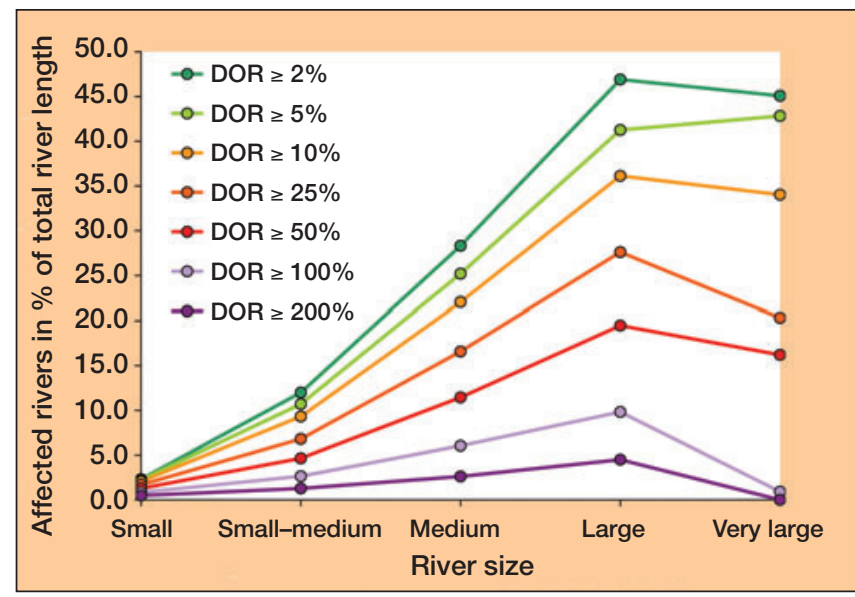

Figure 3. Percent of affected river length for different DOR thresholds. River size classes are defined in Table 2.

Yet smaller streams can provide local ecosystem services, serve as ecological refuges, or may represent headwater reaches important for municipal water supply. Second, the DOR ratio is important. For river reaches with high DOR ratios, major implications for the intra- and interannual flow regimes are to be expected. Smaller ratios may represent critical alterations as well, but of shorter duration or smaller amplitude. Third, it will largely depend on the individual reservoir operation scheme

\begin{tabular}{|c|c|c|c|c|c|c|c|c|c|c|c|}
\hline \multirow[b]{3}{*}{ Region } & \multirow{3}{*}{$\begin{array}{l}\text { \# of } \\
\text { dams }\end{array}$} & \multirow{3}{*}{$\begin{array}{l}\text { Total } \\
\text { storage } \\
\text { capacity } \\
\left(\text { in } \mathrm{km}^{3} \text { ) }\right.\end{array}$} & \multirow{2}{*}{\multicolumn{4}{|c|}{$\begin{array}{c}\text { Extent of affected rivers with a } D O R \geq 2 \% \\
\text { By river size (avg flow in } \mathrm{m}^{3} \mathrm{~s}^{-1} \text { ) }\end{array}$}} & \multirow{2}{*}{\multicolumn{4}{|c|}{$\begin{array}{c}\text { Extent of affected rivers } \\
\text { (all river sizes combined) }\end{array}$}} & \multirow[b]{3}{*}{ Units } \\
\hline & & & & & & & & & & & \\
\hline & & & $1-10$ & $10-100$ & $100-1000$ & $>1000$ & $\geq 2$ & $\geq 10$ & $\geq 50$ & $\geq 100$ & \\
\hline \multirow{2}{*}{ Africa } & \multirow{2}{*}{726} & \multirow{2}{*}{997.2} & 21.5 & 23.6 & 18.5 & 11.0 & 74.6 & 59.3 & 34.7 & 21.9 & $10^{3} \mathrm{~km}$ \\
\hline & & & 2.9 & 9.3 & 18.8 & 43.2 & 6.6 & 5.3 & 3.1 & 1.9 & $\%{ }^{*}$ \\
\hline \multirow{2}{*}{ Asia } & \multirow{2}{*}{1906} & \multirow{2}{*}{1624.9} & 25.7 & 50.2 & 46.2 & 34.2 & 156.3 & 119.7 & 59.7 & 32.2 & $10^{3} \mathrm{~km}$ \\
\hline & & & 1.6 & 9.3 & 25.0 & 54.9 & 6.6 & 5.1 & 2.5 & 1.4 & $\%{ }^{*}$ \\
\hline \multirow{2}{*}{ Australia } & \multirow{2}{*}{253} & \multirow{2}{*}{95.5} & 4.8 & 9.5 & 5.4 & 0.0 & 19.6 & 17.2 & 9.9 & 4.6 & $10^{3} \mathrm{~km}$ \\
\hline & & & 2.4 & 15.2 & 44.7 & 0.0 & 7.1 & 6.2 & 3.6 & 1.7 & $\%{ }^{*}$ \\
\hline \multirow{2}{*}{ Europe $^{a}$} & \multirow{2}{*}{1424} & \multirow{2}{*}{892.2} & 22.1 & 39.9 & 33.5 & 8.9 & 104.4 & 79.4 & 38.8 & 20.8 & $10^{3} \mathrm{~km}$ \\
\hline & & & 3.9 & 21.6 & 54.1 & 79.6 & 12.6 & 9.6 & 4.7 & 2.5 & $\%{ }^{*}$ \\
\hline \multirow{2}{*}{$\begin{array}{l}\text { North } \\
\text { America }\end{array}$} & \multirow{2}{*}{2094} & \multirow{2}{*}{1574.6} & 36.0 & 56.2 & 45.6 & 16.5 & 154.3 & 132.5 & 73.5 & 44.8 & $10^{3} \mathrm{~km}$ \\
\hline & & & 5.0 & 23.4 & 54.5 & 79.7 & 14.4 & 12.4 & 6.9 & 4.2 & $\%^{*}$ \\
\hline \multirow{2}{*}{$\begin{array}{l}\text { South } \\
\text { America }^{b}\end{array}$} & \multirow{2}{*}{459} & \multirow{2}{*}{1012.8} & 7.3 & 23.9 & 21.7 & 13.7 & 66.6 & 52.7 & 30.7 & 14.9 & $10^{3} \mathrm{~km}$ \\
\hline & & & 0.6 & 5.8 & 13.4 & 22.4 & 3.5 & 2.8 & 1.6 & 0.8 & $\%^{*}$ \\
\hline \multirow{2}{*}{$\begin{array}{l}\text { Global } \\
\text { total }\end{array}$} & \multirow{2}{*}{6862} & \multirow{2}{*}{6197.1} & 117.5 & 203.3 & 170.8 & 84.3 & 575.9 & 460.7 & 247.3 & 139.2 & $10^{3} \mathrm{~km}$ \\
\hline & & & 2.3 & 12.0 & 28.3 & 46.7 & 7.6 & 6.1 & 3.3 & 1.8 & $\%^{*}$ \\
\hline \multirow{2}{*}{$\begin{array}{l}\text { Global } \\
\geq 0.5 \mathrm{~km}^{3}\end{array}$} & \multirow{2}{*}{1122} & \multirow{2}{*}{5689.0} & 10.1 & 66.7 & 130.9 & 80.2 & 287.9 & 253.1 & 156.5 & 92.9 & $10^{3} \mathrm{~km}$ \\
\hline & & & 0.2 & 3.9 & 21.7 & 44.4 & 3.8 & 3.3 & 2.1 & 1.2 & $\%{ }^{*}$ \\
\hline
\end{tabular}


and/or additional effects, such as the level of water abstraction, whether the downstream flows are compromised. Some dams with large potential capacities, such as the Owen Falls Dam across the White Nile downstream of Lake Victoria, are not used to maximize storage but are operated as run-of-the-river hydropower plants; for other dams, the implementation of environmental flow standards may mitigate the indicated effects. Finally, we recognize that ecological effects may vary and that some river habitats may be more threatened than others by a certain level of regulation. Clearly, more research is needed regarding the associated ecological consequences.

There are many small reservoirs that are not included in GRanD. In particular, our finding that the smaller river size classes show lower impact levels (Table 2; Figure 3) may be severely skewed by the omission of small reservoirs, which are typically located on smaller rivers. Also, though they may contribute less to the overall alteration of flow regimes as a result of their limited storage capacities, small dams can still have a profound effect on river fragmentation.

In order to assess the improvement of GRanD over previous datasets and to test the sensitivity of our DOR estimates with respect to smaller reservoirs, we repeated the calculations using only those reservoirs with a storage capacity larger than $0.5 \mathrm{~km}^{3}$, which have been the focus of previous global dam databases. We found that this limitation reduced the extent of affected rivers by about $50 \%$ (DOR $\geq 2 \%$; Table 3 ), with the largest differences occurring for small rivers. This result illustrates that smaller reservoirs are responsible for a substantial increase in the spatial extent of affected rivers, despite their relatively small contribution in total global reservoir capacity.

Intrinsically, our model approach is subject to various uncertainties. Beyond technical issues (see WebPanels 1-3), some aspects could not be addressed because of a lack of data, such as the role of dam operation or sediment trapping. Moreover, river deltas are not represented properly by the HydroSHEDS river network and are thus not fully included in the estimates. Finally, our study only accounts for impacts from upstream reservoirs on downstream river reaches; yet, for many additional upstream tributaries, connectivity and species migration routes may be disrupted or impeded either directly by the presence of downstream dams or indirectly by downstream rivers being exposed to altered flow regimes. Overall, and given the nature of most uncertainties and omissions, we believe that our estimates of the extent of affected rivers are therefore conservative.

\section{Discussion and implications}

The quality of available data related to dams and reservoirs is critical in global efforts to better understand the threats to, and to ensure the conservation of, freshwater ecosystems and their dependent natural communities (eg Nilsson et al. 2005; Döll et al. 2009; Vörösmarty et al.
2009, 2010). Indeed, previous studies of the impacts of dams and reservoirs on ecology and human society, from local to global scales, have hitherto been restricted, including only a subset of these structures in any analysis. Similar data constraints have limited the degree to which new construction, operation, and decommissioning of dams are informed decisions. In an era of continued dam construction, particularly in economically developing and water-scarce nations, these decisions must rely on the best available data to guarantee the future sustainability of water resources and for the benefit of the people dependent upon them. For example, nearly 30 new dams were under construction in the Shatt al Arab (Euphrates-Tigris) Basin as of 2004, a basin rife with political conflict, poverty, and severe drought (Altinbilek 2004). If the decisions thus far on location, size, and operation of these dams have suffered from misinformation or insufficient data, then the challenges presented to this basin may be further exacerbated. Moreover, given that many regions will be challenged by climate-changeinduced alterations in river flow regimes, different ways of managing dams and reservoirs may favor or limit adaptive capacity (Palmer et al. 2008).

With the increased recognition of the value of functioning freshwater ecosystems (Naiman et al. 2002), the challenge is to adapt traditional approaches of flow management and meet the needs of both ecosystems and people (Arthington et al. 2010). Previous data on dams and reservoirs have been successfully applied to global waterresource management efforts in terms of identifying biomes, nations, or basins for finer-scale studies. The next step is to move concertedly toward addressing critical questions regarding (1) the global distribution of impacts at the river reach scale, (2) the relative impacts of individual dams and reservoirs within basins, and (3) the impacts in small- and medium-sized basins.

With its increased spatial accuracy and attribute coverage, GRanD is a highly versatile geodatabase that is available to support new regional or global analyses at unprecedented spatial resolution, sophistication, and reliability. As evidence for its utility, Vörösmarty et al. (2010) have incorporated the database as one indicator to derive a first-time spatially explicit global assessment of threats to human water security and river biodiversity. Also, in a related study, Richter et al. (2010) have used our layer of affected river reaches to derive a first-time approximation of the number of people that are potentially affected downstream of reservoirs. Their results show that, globally, 472 million people are living in rural areas downstream of large dams in close proximity $(<10$ $\mathrm{km}$ ) to impacted rivers (DOR $>10 \%$ ).

GRanD will also benefit decisions regarding non-damrelated water management schemes, by providing a larger context within which these projects operate. For example, regions such as the Upper Danube and Southern Iberia have little remaining uninterrupted free-flowing river distance, resulting in loss of habitat for dependent 
species. Water management and/or river restoration schemes in these ecoregions may include designs that offer restoration of essential habitat, while alternative irrigation practices and efficiency gains can help in meeting human needs. We advocate that a more holistic "river network mindset" is required in future strategic planning, and that river basin development and management plans use approaches similar to our DOR assessment to inform decisions regarding the distribution of new dams and/or the operation of existing dams. Additional data and novel assessment techniques may reveal the cumulative effects of dams on the entire river system, helping to identify or restore important linkages and avoid critical thresholds. We envision that regional management schemes could also be "optimized" by prioritizing the siting of new dams based on which locations would have the lowest estimated cumulative impacts downstream. Similarly, dams can be identified where changes in release patterns and operation schemes - or technical interventions, such as fish bypass facilities - would be most likely to improve environmental flows and/or ecosystem services.

One of the most important points to be made with regard to GRanD is a call for active contribution in terms of new data input, data updates, and quality control. This database's continuing utility is largely dependent on the accuracy of its content, including current and robust attribute data, which requires consistent input from the people and organizations that have the most detailed and accurate data on dams and reservoirs in their respective region. For example, the possibilities for conducting innovative, multiscale social analyses will grow as GRanD receives demographic data associated with individual dams and reservoirs, such as size and location of the population served, size of population displaced, estimates of downstream livelihood dependence, and other related economic factors. As the list of desired applications expands, so must the data contributed to GRanD.

\section{Acknowledgements}

We thank the International Project Office of the Global Water System Project for coordinating and facilitating the development of GRanD through several international workshops; the German Federal Ministry of Education and Research (BMBF) for their financial support; and the data-contributing organizations that provided their individual databases for incorporation in GRanD (see WebTable 1). GRanD is freely available for non-commercial use at www.gwsp.org/85.html and http://sedac.ciesin.columbia.edu/pfs/grand.html.

\section{References}

Altinbilek D. 2004. Development and management of the Euphrates-Tigris Basin. Int J Water Resour D 20: 15-33.

Arthington AH, Naiman RJ, McClain ME, and Nilsson C. 2010. Preserving the biodiversity and ecological services of rivers: new challenges and research opportunities. Freshwater Biol 55: $1-16$.
Arthington AH and Welcomme RL. 1995. The condition of large river systems of the world. In: Voigtlander CW (Ed). Proceedings of the World Fisheries Congress. New Delhi, India: Oxford and IBH Publishing.

Baisre JA and Arboleya Z. 2006. Going against the flow: effects on river damming in Cuban fisheries. Fish Res 81: 283-92.

Berga L, Buil JM, Bofill E, et al. 2006. Dams and reservoirs, societies and environment in the 21st century. Proceedings of the International Symposium on Dams in Societies of the 21st Century; 18 Jun 2006; Barcelona, Spain. London, UK: Taylor and Francis Group.

Bruinsma J. 2009. The resource outlook to 2050: by how much do land, water and crop yields need to increase by 2050? Rome, Italy: Food and Agriculture Organization of the United Nations.

Bunn SE and Arthington AH. 2002. Basic principles and consequences of altered hydrological regimes for aquatic biodiversity. Environ Manage 30: 492-507.

Carlisle DM, Wolock DM, and Meador MR. 2011. Alteration of streamflow magnitudes and potential ecological consequences: a multiregional assessment. Front Ecol Environ 9: 264-70.

Černý J, Copp GH, Kováč V, et al. 2003. Initial impact of the Gabćḱkovo hydroelectric scheme on the species richness and composition of fish assemblages in the Slovak flood plain, River Danube. River Res Appl 19: 749-66.

Chao BF, Wu YH, and Li YS. 2008. Impact of artificial reservoir water impoundment on global sea level. Science 320: 212-14.

Del Sontro D, McGinnis DF, Sobek S, et al. 2010. Extreme methane emissions from a Swiss hydropower reservoir: contribution from bubbling sediments. Environ Sci Technol 44: 2419-25.

Döll P, Fiedler K, and Zhang J. 2009. Global-scale analysis of river flow alterations due to water withdrawals and reservoirs. Hydrol Earth Syst Sci 13: 2413-32.

Downing JA, Prairie JT, Cole JJ, et al. 2006. The global abundance and size distribution of lakes, ponds, and impoundments. Limnol Oceanogr 51: 2388-97.

Dudgeon D, Arthington AH, Gessner MO, et al. 2006. Freshwater biodiversity: importance, threats, status and conservation challenges. Biol Rev 81: 163-82.

Dynesius M and Nilsson C. 1994. Fragmentation and flow regulation of river systems in the northern third of the world. Science 266: 753-62.

Ericson JP, Vörösmarty CJ, Dingman SL, et al. 2006. Effective sealevel rise in deltas: sources of change and human-dimension implications. Global Planet Change 50: 63-82.

Freeman MC and Marcinek PA. 2006. Fish assemblage responses to water withdrawals and water supply reservoirs in piedmont streams. J Environ Manage 38: 435-50.

Gleick PH. 2000. The world's water 2000-2001: the biennial report on freshwater resources. Washington, DC: Island Press.

Hanasaki N, Kanae S, and Oki T. 2006. A reservoir operation scheme for global river routing models. J Hydrol 327: 22-41.

Harrison JA, Maranger RJ, Alexander RB, et al. 2009. The regional and global significance of nitrogen removal in lakes and reservoirs. Biogeochemistry 93: 143-57.

ICOLD (International Commission on Large Dams). 1998-2009. World register of dams. Version updates 1998-2009. Paris, France: ICOLD. www.icold-cigb.net. Viewed 23 Mar 2011.

Jansson R, Nilsson C, and Renöfält B. 2000. Fragmentation of riparian floras in rivers with multiple dams. Ecology 81: 899-903.

Lehner B and Döll P. 2004. Development and validation of a global database of lakes, reservoirs and wetlands. J Hydrol 296: 1-22.

Lehner B, Verdin K, and Jarvis A. 2008. New global hydrography derived from spaceborne elevation data. Eos Trans AGU 89: 93-94.

Lima IBT, Ramos FM, Bambace LAW, and Rosa RR. 2008. 
Methane emissions from large dams as renewable energy resources: a developing nation perspective. Mitig Adap Strategies Glob Chang 13: 193-206.

Naiman RJ, Bunn SE, Nilsson C, et al. 2002. Legitimizing fluvial ecosystems as users of water: an overview. Environ Manage 30: 455-67.

Nilsson C, Reidy CA, Dynesius M, and Revenga C. 2005. Fragmentation and flow regulation of the world's large river systems. Science 308: 405-08.

Palmer MA, Reidy CA, Nilsson C, et al. 2008. Climate change and the world's river basins: anticipating management options. Front Ecol Environ 6: 81-89.

Poff NL, Allan JD, Bain MB, et al. 1997. The natural flow regime: a new paradigm for riverine conservation and restoration. BioScience 47: 769-84.

Poff NL, Richter B, Arthington AH, et al. 2010. The Ecological Limits of Hydrologic Alteration (ELOHA): a new framework for developing regional environmental flow standards. Freshwater Biol 55: 147-70.

Pringle CM, Freeman MC, and Freeman BJ. 2000. Regional effects of hydrologic alterations on riverine macrobiota in the New World: tropical-temperate comparisons. BioScience 50: 807-23.

Renwick WH, Smith SV, Bartley JD, and Buddemeier RW. 2005. The role of impoundments in the sediment budget of the conterminous United States. Geomorphology 71: 99-111.

Richter BD, Postel S, Revenga C, et al. 2010. Lost in development's shadow: the downstream human consequences of dams. Water Alternatives 3: 14-42.

Scudder T. 2006. The future of large dams: dealing with social, environmental, institutional and political costs. London, UK: Earthscan.

Shiklomanov IA. 2000. Appraisal and assessment of world water resources. Water Int 25: 11-32.

St Louis VL, Kelly CA, Duchemin E, et al. 2000. Reservoir surfaces as sources of greenhouse gases to the atmosphere: a global estimate. BioScience 50: 766-75.

Syvitski JPM, Vörösmarty CJ, Kettner AJ, and Green P. 2005. Impact of humans on the flux of terrestrial sediment to the global coastal ocean. Science 308: 376-80.

Syvitski JPM, Kettner AJ, Overeem I, et al. 2009. Sinking deltas due to human activities. Nat Geosci 2: 681-86.

Tockner K, Bunn S, Gordon C, et al. 2008. Flood plains: critically threatened ecosystems. In: Polunin NVC (Ed). Aquatic ecosystems. Cambridge, UK: Cambridge University Press.

Vörösmarty CJ, Sharma KP, Fekete BM, et al. 1997. The storage and aging of continental runoff in large reservoir systems of the world. Ambio 26: 210-19.

Vörösmarty CJ, Meybeck M, Fekete B, et al. 2003. Anthropogenic sediment retention: major global-scale impact from the population of registered impoundments. Global Planet Change 39: $169-90$.

Vörösmarty CJ, Day J, DeSherbinin A, and Syvitski J. 2009. Battling to save the world's river deltas. B Atom Sci 65: 31-43.

Vörösmarty CJ, McIntyre PB, Gessner MO, et al. 2010. Global threats to human water security and river biodiversity. Nature 467: 555-61.

WCD (World Commission on Dams). 2000. Dams and development: a framework for decision making. London, UK Earthscan.

Wisser D, Frolking S, Douglas EM, et al. 2010. The significance of local water resources captured in small reservoirs for crop production: a global-scale analysis. J Hydrol 384: 264-75.

Xu K and Milliman JD. 2009. Seasonal variations of sediment discharge from the Yangtze River before and after impoundment of the Three Gorges Dam. Geomorphology 104: 276-83.

${ }^{6}$ University of Frankfurt, Frankfurt, Germany; ${ }^{7}$ Global Water System Project, International Project Office, Bonn, Germany; ${ }^{8}$ Food and Agriculture Organization of the United Nations, Rome, Italy; ${ }^{9}$ University of Yamanashi, Yamanashi, Japan; ${ }^{10}$ Department of Ecology and Environmental Science, Umeå University, Umeå, Sweden; ${ }^{11}$ University of Greifswald, Greifswald, Germany; ${ }^{12}$ Conservation Science Program, World Wildlife Fund, Washington, DC; ${ }^{13}$ University of New Hampshire, Durham, NH

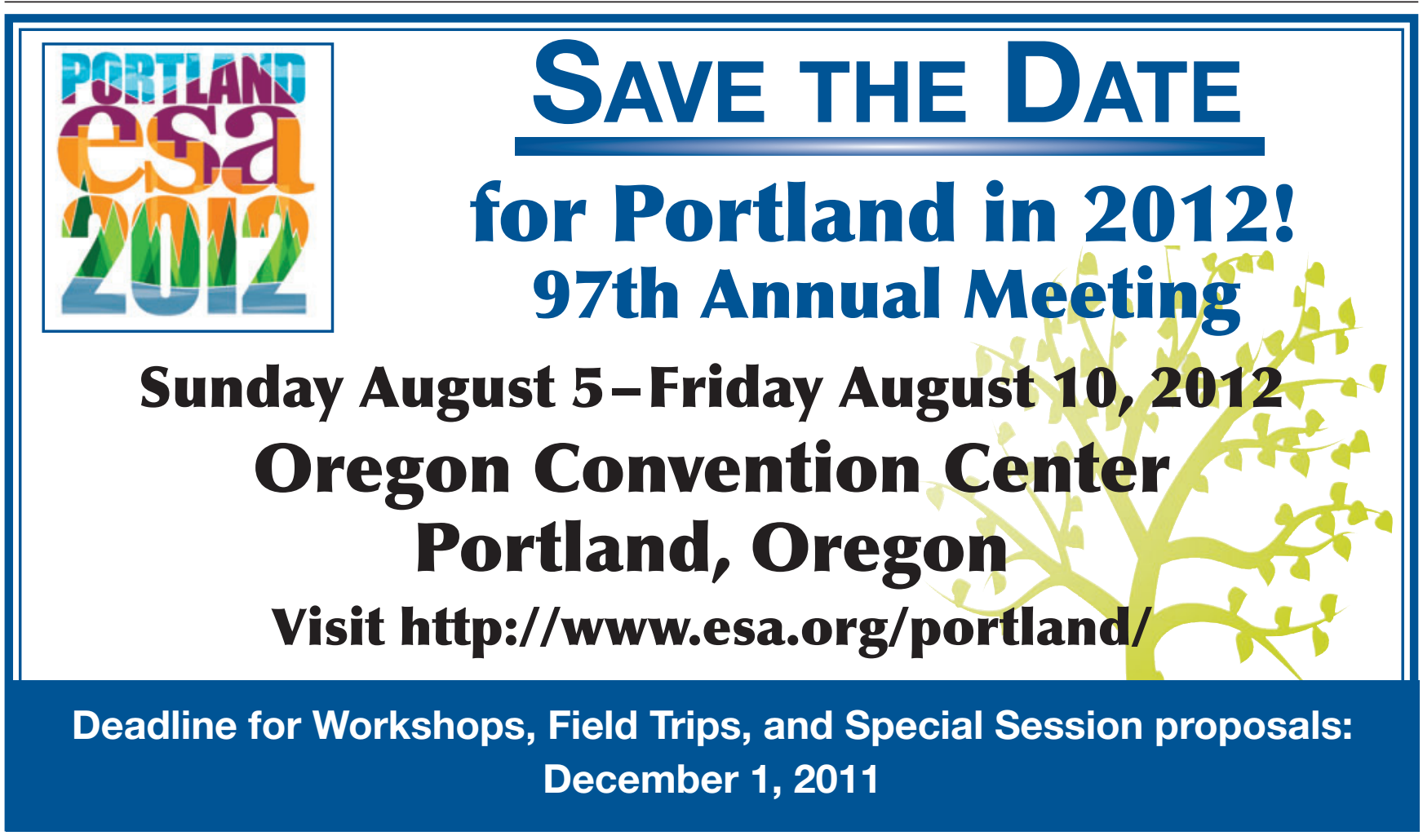




\section{WebPanel 1. Development of GRanD}

The most comprehensive global dam database - the World Register of Dams - is compiled by the International Commission on Large Dams (ICOLD) and currently lists more than 33000 records of large dams and their attributes (ICOLD 1998-2009). However, this inventory is not georeferenced, limiting its utility for many applications. Water resource managers typically need to allocate reservoirs to sub-basins, link them to the drainage network, or relate them to population centers and irrigated areas. Biological and geophysical Earth system studies, conservation planning efforts, and restoration projects all require georeferenced data, preferably with extensive attribute information, spanning both local and global scales.

In previous attempts, several researchers and organizations have created their own georeferenced, global and regional datasets of dams and reservoirs, mostly by identifying the largest of them on paper maps and compiling attribute information from various sources, including national archives and the internet. These databases, however, vary widely in their number of records, the quality of attribute data, and their spatial resolution, ranging from coarse coordinates to lumped national or regional assignments. Among them, the most extensive, publicly available global georeferenced compilation contains some 1500 large reservoirs, a very small number as compared with the globally estimated 50000 large reservoirs. Also, the absence of a high-resolution global river network precluded use of even the best of these datasets in routed hydrologic analyses, because dams and reservoirs could not be linked to detailed river courses.

The development of GRanD primarily aimed at compiling the available reservoir and dam information (WebTable I); correcting it through extensive cross-validation, error checking, and identification of duplicate records, attribute conflicts, or mismatches; and completing missing information from new sources or statistical approaches (see below). The dams were geospatially referenced and assigned to polygons depicting reservoir outlines at high spatial resolution. Although the main focus was to include all reservoirs with a storage capacity of more than $0.1 \mathrm{~km}^{3}$, many smaller reservoirs were added if data were available. In instances where natural lakes are regulated by dams, such as Africa's Lake Victoria, only the added storage volume was considered. Finally, some dams were included because of their importance, such as India's Farakka Barrage, which diverts water from the Ganges River, even if they do not create a traditional reservoir. For more details on the development of GRanD, see the Technical Documentation available at www.gwsp.org/85.html and http://sedac.ciesin.columbia.edu/pfs/grand.html.

In the course of constructing GRanD, two equations were derived and applied in order to complete missing reservoir volumes:
$V=0.678(A \cdot h)^{0.9229}$
$V=30.684 A^{0.9578}$
(Eq 2)

where $V=$ reservoir volume in $10^{6} \mathrm{~m}^{3} ; A=$ reservoir area in $\mathrm{km}^{2} ;$ and $h=$ dam height in $\mathrm{m}$. Equation I was used to estimate missing reservoir volumes if both area and dam height were available $\left(r^{2}=0.92\right)$; Equation 2 was used if only the reservoir area was available $\left(r^{2}=0.80\right)$. Both equations were determined by a statistical regression analysis of 5824 reservoirs included in GRanD that were selected based on the completeness and reliability of their data (for details, see GRanD Technical Documentation). 


\section{WebPanel 2. Estimating the global distribution of reservoirs with a Pareto model}

The Pareto distribution can be expressed in the power law form of $N=\alpha A^{-\beta}$, where $N$ is the number of reservoirs with a surface area larger than $A$, and $\alpha$ and $\beta$ are the parameters to be fitted. In order to apply this approach to GRanD, we first excluded reservoirs smaller than $10 \mathrm{~km}^{2}$ because we consider these increasingly incomplete in the records of GRanD. We then derived the (uncorrected) global reservoir distribution as:

$N=13964 A^{-0.7807} \quad($ Eq 3)

where $N$ is the number of reservoirs larger than $A$, and $A$ is the reservoir surface area in $\mathrm{km}^{2}$ (WebFigure 1 ). Note that while $r^{2}=0.994$, the gradient of the trendline strongly depends on the underlying data and assumes true completeness of the records for reservoirs equal or larger than $10 \mathrm{~km}^{2}$, which is not warranted in GRanD. Also, the construction of reservoirs larger than $1000 \mathrm{~km}{ }^{2}$ seems increasingly case-specific and aligns less closely with the derived statistical distribution.

Following the approach by Downing et al. (2006), the value for $\alpha$ in Equation 3 can be corrected as follows:

$\alpha=\frac{N_{G}}{\left(A_{G \min }^{-\beta}-A_{G \max }^{-\beta}\right)}$

where $N_{G}$ is the total number of reservoirs in GRanD in the size range $10-1000 \mathrm{~km}^{2}\left(N_{G}=203 \mathrm{I}\right) ; A_{G \min }$ and $A_{G \max }$ are 10 and $1000\left[\mathrm{~km}^{2}\right]$, respectively; and $\beta=0.7807$. Through this correction, the global reservoir distribution is:

$N=12604 A^{-0.7807} \quad($ Eq 5)

The number of reservoirs in a size range (as shown in Table I) is:

$N_{A_{\min }-A_{\max }}=\alpha \cdot\left(A_{\min }^{-\beta}-A_{\max }^{-\beta}\right)$

where $A_{\min }$ and $A_{\max }$ are the lower and upper area limits of the size class to be calculated, and $\alpha$ is the corrected $\alpha$ of Equation 4 (ie $\alpha=12604$ ).

The average area in a size range is:

$\bar{A}_{A_{\min }-A_{\max }}=\beta \cdot \frac{-A_{\max } A_{\min }^{-\beta}+A_{\max }^{-\beta} A_{\min }}{(\beta-I)\left(A_{\max }^{-\beta}-A_{\min }^{-\beta}\right)}$

In Table I, the total area for the Pareto model is calculated by multiplying the number of reservoirs with the mean area per size class. The total volume is then calculated by applying Equation 2 (see WebPanel I) to the mean area per size class. Note that this approach assumes a linear relationship between reservoir area and volume; because the exponent in Equation 2 is close to I, the error has been tested to be less than $1 \%$.

\section{WebPanel 3. Calculation of DOR values}

Using standard geographic information system (GIS) functionality, we accumulated the storage capacity of all recorded GRanD reservoirs along the HydroSHEDS river network, providing a "total upstream storage capacity" for every river reach. At the applied HydroSHEDS pixel resolution of 15 arc-seconds $(\sim 500 \mathrm{~m})$, the perennial stream network of rivers larger than $1 \mathrm{~m}^{3} \mathrm{~s}^{-1}$ consists of about 3.5 million reaches with an average reach length of $2.2 \mathrm{~km}$. HydroSHEDS also includes estimates of long-term (196I-1990) average annual river flows, based on coarse-scale runoff estimates from the global water balance model WaterGAP (Alcamo et al. 2003; Döll et al. 2003). We thus could calculate DOR ratios for all river reaches by comparing the total accumulated upstream storage capacity with the average flow at every reach location. Finally, we computed the total lengths of affected river reaches, and we grouped the derived results by river sizes from small to very large and by DOR ratios from low to high (Figure 3; Tables 2 and 3;WebTable 2).

Like with all model approaches, our study results are limited by uncertainties, including errors in the reported storage capacities of GRanD; limited accuracy of the assigned dam coordinates; errors in the drainage network of HydroSHEDS; and uncertainties in the discharge estimates, which are ultimately based on a coarse-scale global water balance model. Given that the HydroSHEDS river network is derived from a digital elevation model, its accuracy is influenced by pixel resolution. We evaluated the quality of the length estimates by comparing them to selected river courses that were digitized at high precision from remote-sensing imagery (including the 10 longest rivers globally). This comparison indicated average errors of less than $5 \%$ in our length calculations. 
WebTable 1. Institutions that participated in the development of GRanD (in alphabetical order), their provided datasets, focus of contribution, and number of provided records

\begin{tabular}{|c|c|c|}
\hline Institution & Provided data and focus of contribution & \# of independent data records ${ }^{a}$ \\
\hline $\begin{array}{l}\text { European Environment } \\
\text { Agency, Denmark }\end{array}$ & Provided point and attribute data for Europe ${ }^{b}$ & 3793 (Europe) \\
\hline $\begin{array}{l}\text { Food and Agriculture Organization } \\
\text { of the United Nations (FAO) }\end{array}$ & $\begin{array}{l}\text { Provided point and attribute data for Africa } \\
\left(\text { AQUASTAT }{ }^{c} \text { ) }\right.\end{array}$ & II 38 (Africa) \\
\hline McGill University, Canada & $\begin{array}{l}\text { Provided GLWD }{ }^{\text {d }} \text {; updated/improved data for } \\
\text { Australia }{ }^{\mathrm{e}} \text { and globally; final global data } \\
\text { consolidation of GRanD }\end{array}$ & $\begin{array}{l}\text { I226 (GLWD); } \\
846 \text { (Australia) }\end{array}$ \\
\hline The Nature Conservancy (TNC), US & Updated/improved data for South America & 149 (South America) \\
\hline University of Frankfurt, Germany & $\begin{array}{l}\text { Coauthor of GLWD'; updated/improved data } \\
\text { for China }\end{array}$ & 568 (China) \\
\hline University of Greifswald, Germany & $\begin{array}{l}\text { Provided global point and attribute data; } \\
\text { updated/improved data for Europe }\end{array}$ & $\begin{array}{l}8157 \text { (global, excluding the US, China, } \\
\text { Africa); } 4230 \text { (Europe) }\end{array}$ \\
\hline University of Kassel, Germany & Coauthor of GLWD ${ }^{d}$ & - \\
\hline University of New Hampshire, US & $\begin{array}{l}\text { Provided global point and attribute data; } \\
\text { updated/improved data for North America } \\
\text { (including NIDf }\end{array}$ & I 897 (US); 236 (Canada); 226 (Mexico) \\
\hline Umeå University, Sweden & Provided global point and attribute data & $\begin{array}{l}5575 \text { (global, excluding North America, } \\
\text { Europe, Russia) }\end{array}$ \\
\hline University of Yamanashi, Japan & $\begin{array}{l}\text { Provided global point, polygon, and attribute } \\
\text { data; updated/improved data for Japan }\end{array}$ & $\begin{array}{l}\text { I5 } 073 \text { points }{ }^{g}, 4648 \text { polygons (global); } \\
560 \text { (Japan) }\end{array}$ \\
\hline World Wildlife Fund (WWF), US & $\begin{array}{l}\text { Coauthor of GLWD'; updated/improved } \\
\text { data for Asia }\end{array}$ & 215 (Asia) \\
\hline \multicolumn{3}{|c|}{ 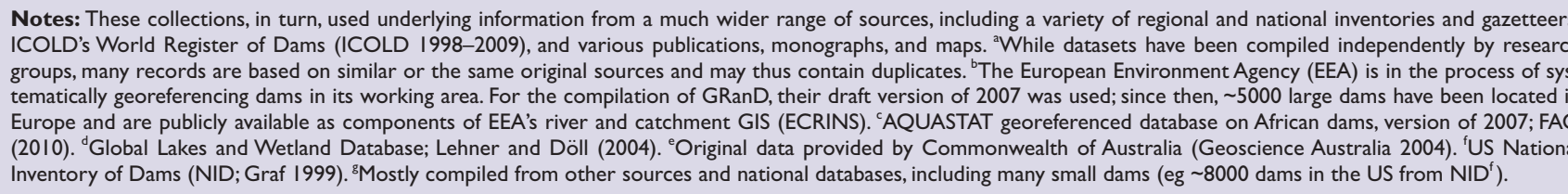 } \\
\hline
\end{tabular}




\begin{tabular}{|c|c|c|c|c|c|c|c|c|c|c|c|}
\hline \multirow[b]{3}{*}{ Region } & \multirow{3}{*}{$\begin{array}{l}\text { \# of } \\
\text { dams }\end{array}$} & \multirow{3}{*}{$\begin{array}{c}\text { Total } \\
\text { storage } \\
\text { capacity } \\
\left(\text { in } \mathrm{km}^{3} \text { ) }\right.\end{array}$} & \multirow{2}{*}{\multicolumn{4}{|c|}{$\frac{\text { Extent of affected rivers with a } D O R \geq 2 \%}{\text { By river size (avg flow in } \mathrm{m}^{3} \mathrm{~s}^{-1} \text { ) }}$}} & \multicolumn{4}{|c|}{$\begin{array}{l}\text { Extent of affected rivers } \\
\text { (all river sizes combined) }\end{array}$} & \multirow[b]{3}{*}{ Units } \\
\hline & & & & & & & & By D & $\mathbf{R}$ (\%) & & \\
\hline & & & $1-10$ & $10-100$ & $100-1000$ & $>1000$ & $\geq 2$ & $>10$ & $>50$ & $>100$ & \\
\hline US & 1906 & 767.5 & $\begin{array}{l}35.1 \\
10.3\end{array}$ & $\begin{array}{l}52.5 \\
46.3\end{array}$ & $\begin{array}{l}31.8 \\
81.9\end{array}$ & $\begin{array}{r}8.8 \\
78.1\end{array}$ & $\begin{array}{r}128.2 \\
25.5\end{array}$ & $\begin{array}{r}110.6 \\
22.0\end{array}$ & $\begin{array}{l}63.0 \\
12.5\end{array}$ & $\begin{array}{r}39.3 \\
7.8\end{array}$ & $\begin{array}{l}10^{3} \mathrm{~km} \\
\% \\
*\end{array}$ \\
\hline China & 770 & 451.0 & $\begin{array}{r}13.9 \\
4.4\end{array}$ & $\begin{array}{l}22.5 \\
20.5\end{array}$ & $\begin{array}{l}17.9 \\
46.1\end{array}$ & $\begin{array}{l}10.5 \\
78.9\end{array}$ & $\begin{array}{l}64.8 \\
13.6\end{array}$ & $\begin{array}{l}48.5 \\
10.2\end{array}$ & $\begin{array}{r}25.1 \\
5.3\end{array}$ & $\begin{array}{r}14.6 \\
3.1\end{array}$ & $\begin{array}{l}10^{3} \mathrm{~km} \\
\%\end{array}$ \\
\hline India & 320 & 262.2 & $\begin{array}{l}4.4 \\
2.8\end{array}$ & $\begin{array}{l}13.1 \\
20.7\end{array}$ & $\begin{array}{l}11.4 \\
53.1\end{array}$ & $\begin{array}{r}4.0 \\
62.0\end{array}$ & $\begin{array}{l}33.0 \\
13.1\end{array}$ & $\begin{array}{l}28.1 \\
11.2\end{array}$ & $\begin{array}{r}11.5 \\
4.6\end{array}$ & $\begin{array}{l}4.9 \\
1.9\end{array}$ & $\begin{array}{l}10^{3} \mathrm{~km} \\
\%\end{array}$ \\
\hline Canada & 228 & 860.7 & $\begin{array}{l}1.7 \\
0.5\end{array}$ & $\begin{array}{l}5.4 \\
4.2\end{array}$ & $\begin{array}{l}13.5 \\
30.4\end{array}$ & $\begin{array}{r}7.4 \\
81.7\end{array}$ & $\begin{array}{r}28.0 \\
5.0\end{array}$ & $\begin{array}{r}23.9 \\
4.2\end{array}$ & $\begin{array}{r}12.8 \\
2.3\end{array}$ & $\begin{array}{l}7.9 \\
1.4\end{array}$ & $\begin{array}{l}10^{3} \mathrm{~km} \\
\%\end{array}$ \\
\hline Russia & 50 & 811.8 & $\begin{array}{l}0.5 \\
0.1\end{array}$ & $\begin{array}{l}1.1 \\
0.5\end{array}$ & $\begin{array}{l}6.4 \\
7.7\end{array}$ & $\begin{array}{l}17.3 \\
58.2\end{array}$ & $\begin{array}{r}25.3 \\
2.5\end{array}$ & $\begin{array}{r}19.3 \\
1.9\end{array}$ & $\begin{array}{r}12.2 \\
1.2\end{array}$ & $\begin{array}{l}5.9 \\
0.6\end{array}$ & $\begin{array}{l}10^{3} \mathrm{~km} \\
\%\end{array}$ \\
\hline Brazil & 179 & 530.3 & $\begin{array}{l}2.3 \\
0.4\end{array}$ & $\begin{array}{l}6.5 \\
3.4\end{array}$ & $\begin{array}{l}8.0 \\
9.7\end{array}$ & $\begin{array}{r}7.5 \\
22.4\end{array}$ & $\begin{array}{r}24.3 \\
2.7\end{array}$ & $\begin{array}{r}19.5 \\
2.2\end{array}$ & $\begin{array}{l}9.5 \\
1.1\end{array}$ & $\begin{array}{l}2.8 \\
0.3\end{array}$ & $\begin{array}{l}10^{3} \mathrm{~km} \\
\%\end{array}$ \\
\hline Australia & 188 & 78.6 & $\begin{array}{l}4.5 \\
2.6\end{array}$ & $\begin{array}{r}9.1 \\
17.1\end{array}$ & $\begin{array}{r}4.6 \\
44.4 \\
\end{array}$ & $\begin{array}{l}0.0 \\
0.0\end{array}$ & $\begin{array}{r}18.2 \\
7.7\end{array}$ & $\begin{array}{r}16.2 \\
6.8\end{array}$ & $\begin{array}{l}9.6 \\
4.1\end{array}$ & $\begin{array}{l}4.5 \\
1.9\end{array}$ & $\begin{array}{l}10^{3} \mathrm{~km} \\
\%\end{array}$ \\
\hline South Africa & 271 & 33.1 & $\begin{array}{r}8.1 \\
36.7\end{array}$ & $\begin{array}{r}6.1 \\
68.0\end{array}$ & $\begin{array}{r}1.9 \\
77.3 \\
\end{array}$ & $\begin{array}{l}0.0 \\
0.0\end{array}$ & $\begin{array}{l}16.1 \\
48.1\end{array}$ & $\begin{array}{l}14.1 \\
42.3\end{array}$ & $\begin{array}{r}8.7 \\
26.1\end{array}$ & $\begin{array}{r}5.5 \\
16.4 \\
\end{array}$ & $\begin{array}{l}10^{3} \mathrm{~km} \\
\%\end{array}$ \\
\hline Japan & 543 & 19.6 & $\begin{array}{r}4.7 \\
14.0\end{array}$ & $\begin{array}{r}5.4 \\
57.0\end{array}$ & $\begin{array}{r}1.1 \\
94.7\end{array}$ & $\begin{array}{l}0.0 \\
0.0\end{array}$ & $\begin{array}{l}11.2 \\
25.3\end{array}$ & $\begin{array}{r}6.3 \\
14.2\end{array}$ & $\begin{array}{l}0.9 \\
2.0\end{array}$ & $\begin{array}{l}0.1 \\
0.3\end{array}$ & $\begin{array}{l}10^{3} \mathrm{~km} \\
\%\end{array}$ \\
\hline Spain & 254 & 58.0 & $\begin{array}{r}4.5 \\
24.5\end{array}$ & $\begin{array}{r}4.4 \\
76.6\end{array}$ & $\begin{array}{r}1.4 \\
90.5\end{array}$ & $\begin{array}{l}0.0 \\
0.0\end{array}$ & $\begin{array}{l}10.4 \\
40.3\end{array}$ & $\begin{array}{l}10.1 \\
39.2\end{array}$ & $\begin{array}{r}6.5 \\
25.1\end{array}$ & $\begin{array}{r}4.5 \\
17.4\end{array}$ & $\begin{array}{l}10^{3} \mathrm{~km} \\
\%\end{array}$ \\
\hline Mississippi & 707 & 329.9 & $\begin{array}{l}14.0 \\
11.6\end{array}$ & $\begin{array}{l}22.1 \\
49.5\end{array}$ & $\begin{array}{l}14.4 \\
91.1\end{array}$ & $\begin{array}{r}6.0 \\
96.1\end{array}$ & $\begin{array}{l}56.5 \\
30.2\end{array}$ & $\begin{array}{l}49.7 \\
26.6\end{array}$ & $\begin{array}{l}28.8 \\
15.4\end{array}$ & $\begin{array}{r}18.0 \\
9.6\end{array}$ & $\begin{array}{l}10^{3} \mathrm{~km} \\
\%\end{array}$ \\
\hline Yangtze & 371 & 192.6 & $\begin{array}{l}5.9 \\
5.0\end{array}$ & $\begin{array}{l}10.0 \\
23.8\end{array}$ & $\begin{array}{r}8.1 \\
49.7\end{array}$ & $\begin{array}{r}6.0 \\
81.6\end{array}$ & $\begin{array}{l}29.9 \\
16.4\end{array}$ & $\begin{array}{l}19.9 \\
10.9\end{array}$ & $\begin{array}{l}7.9 \\
4.3\end{array}$ & $\begin{array}{l}3.2 \\
1.7\end{array}$ & $\begin{array}{l}10^{3} \mathrm{~km} \\
\% *\end{array}$ \\
\hline Danube & 184 & 21.9 & $\begin{array}{l}3.1 \\
8.2\end{array}$ & $\begin{array}{r}5.0 \\
37.7\end{array}$ & $\begin{array}{r}4.0 \\
68.4\end{array}$ & $\begin{array}{r}2.5 \\
94.3\end{array}$ & $\begin{array}{l}14.6 \\
24.7\end{array}$ & $\begin{array}{r}8.2 \\
13.9\end{array}$ & $\begin{array}{l}2.3 \\
3.9\end{array}$ & $\begin{array}{l}0.9 \\
1.5\end{array}$ & $\begin{array}{l}10^{3} \mathrm{~km} \\
\%\end{array}$ \\
\hline Parana & 71 & 314.9 & $\begin{array}{l}0.2 \\
0.2\end{array}$ & $\begin{array}{l}1.9 \\
4.3\end{array}$ & $\begin{array}{r}4.5 \\
26.4\end{array}$ & $\begin{array}{r}5.8 \\
97.2\end{array}$ & $\begin{array}{r}12.4 \\
6.6\end{array}$ & $\begin{array}{l}9.9 \\
5.2\end{array}$ & $\begin{array}{l}6.5 \\
3.4\end{array}$ & $\begin{array}{l}1.7 \\
0.9\end{array}$ & $\begin{array}{l}10^{3} \mathrm{~km} \\
\%\end{array}$ \\
\hline Ganges & 81 & 81.7 & $\begin{array}{l}1.1 \\
1.1\end{array}$ & $\begin{array}{l}2.8 \\
6.6\end{array}$ & $\begin{array}{r}3.7 \\
22.8\end{array}$ & $\begin{array}{r}2.3 \\
34.2\end{array}$ & $\begin{array}{l}9.9 \\
5.9\end{array}$ & $\begin{array}{l}7.5 \\
4.4\end{array}$ & $\begin{array}{l}1.7 \\
1.0\end{array}$ & $\begin{array}{l}0.7 \\
0.4\end{array}$ & $\begin{array}{l}10^{3} \mathrm{~km} \\
\%{ }^{*}\end{array}$ \\
\hline $\begin{array}{l}\text { Murray- } \\
\text { Darling }\end{array}$ & 55 & 23.4 & $\begin{array}{l}1.3 \\
7.8\end{array}$ & $\begin{array}{r}5.0 \\
68.0\end{array}$ & $\begin{array}{r}3.6 \\
95.2\end{array}$ & $\begin{array}{l}0.0 \\
0.0\end{array}$ & $\begin{array}{r}9.8 \\
36.2\end{array}$ & $\begin{array}{r}9.1 \\
33.6\end{array}$ & $\begin{array}{r}6.3 \\
23.3\end{array}$ & $\begin{array}{l}2.4 \\
8.9\end{array}$ & $\begin{array}{l}10^{3} \mathrm{~km} \\
\%{ }^{*}\end{array}$ \\
\hline $\begin{array}{l}\text { Euphrates- } \\
\text { Tigris }\end{array}$ & 33 & 228.8 & $\begin{array}{l}0.4 \\
2.2\end{array}$ & $\begin{array}{r}1.7 \\
27.2\end{array}$ & $\begin{array}{r}5.2 \\
87.7\end{array}$ & $\begin{array}{r}0.1 \\
96.3\end{array}$ & $\begin{array}{r}7.4 \\
25.3\end{array}$ & $\begin{array}{r}7.0 \\
23.8\end{array}$ & $\begin{array}{r}5.8 \\
19.9\end{array}$ & $\begin{array}{r}4.2 \\
14.3\end{array}$ & $\begin{array}{l}10^{3} \mathrm{~km} \\
\%\end{array}$ \\
\hline Nile & 9 & 376.5 & $\begin{array}{l}0.0 \\
0.0\end{array}$ & $\begin{array}{l}0.2 \\
0.7\end{array}$ & $\begin{array}{r}0.7 \\
11.1\end{array}$ & $\begin{array}{r}6.2 \\
91.9\end{array}$ & $\begin{array}{l}7.2 \\
7.6\end{array}$ & $\begin{array}{l}6.2 \\
6.6\end{array}$ & $\begin{array}{l}5.7 \\
6.0\end{array}$ & $\begin{array}{l}5.6 \\
5.9\end{array}$ & $\begin{array}{l}10^{3} \mathrm{~km} \\
\%\end{array}$ \\
\hline Zambezi & 59 & 258.0 & $\begin{array}{l}1.5 \\
3.2 \\
\end{array}$ & $\begin{array}{r}1.9 \\
12.2 \\
\end{array}$ & $\begin{array}{r}1.0 \\
16.8 \\
\end{array}$ & $\begin{array}{r}1.1 \\
39.3\end{array}$ & $\begin{array}{l}5.6 \\
7.7 \\
\end{array}$ & $\begin{array}{l}3.5 \\
4.8\end{array}$ & $\begin{array}{l}1.8 \\
2.5 \\
\end{array}$ & $\begin{array}{l}1.3 \\
1.8\end{array}$ & $\begin{array}{l}10^{3} \mathrm{~km} \\
\% *\end{array}$ \\
\hline Volga & 17 & 195.5 & $\begin{array}{l}0.1 \\
0.2\end{array}$ & $\begin{array}{l}0.4 \\
2.1\end{array}$ & $\begin{array}{r}1.3 \\
18.5\end{array}$ & $\begin{array}{r}3.6 \\
88.9\end{array}$ & $\begin{array}{l}5.4 \\
6.2\end{array}$ & $\begin{array}{l}4.2 \\
4.8\end{array}$ & $\begin{array}{l}2.4 \\
2.7\end{array}$ & $\begin{array}{l}0.1 \\
0.1\end{array}$ & $\begin{array}{l}10^{3} \mathrm{~km} \\
\%{ }^{*}\end{array}$ \\
\hline Indus & 25 & 49.3 & $\begin{array}{l}0.1 \\
0.4\end{array}$ & $\begin{array}{l}0.4 \\
4.4\end{array}$ & $\begin{array}{r}2.6 \\
44.5\end{array}$ & $\begin{array}{r}1.9 \\
92.7\end{array}$ & $\begin{array}{r}5.0 \\
12.6 \\
\end{array}$ & $\begin{array}{r}4.3 \\
11.0\end{array}$ & $\begin{array}{l}1.9 \\
4.7\end{array}$ & $\begin{array}{l}0.2 \\
0.6\end{array}$ & $\begin{array}{l}10^{3} \mathrm{~km} \\
\%{ }^{*}\end{array}$ \\
\hline Rio Grande & 35 & 30.4 & $\begin{array}{r}1.0 \\
15.9\end{array}$ & $\begin{array}{r}2.9 \\
84.0\end{array}$ & $\begin{array}{r}0.9 \\
93.3\end{array}$ & $\begin{array}{l}0.0 \\
0.0\end{array}$ & $\begin{array}{r}4.8 \\
45.3\end{array}$ & $\begin{array}{r}4.7 \\
44.8\end{array}$ & $\begin{array}{r}4.6 \\
43.9\end{array}$ & $\begin{array}{r}4.5 \\
42.7\end{array}$ & $\begin{array}{l}10^{3} \mathrm{~km} \\
\%^{*}\end{array}$ \\
\hline
\end{tabular}

Notes: "For the results "by river size", the percent value refers to all rivers of the respective size class in the region; for the results "by DOR", the percent value refers to all rivers of all size classes in the region. 


\section{WebReferences}

Alcamo J, Döll P, Henrichs T, et al. 2003. Development and testing of the WaterGAP 2 global model of water use and availability. Hydrol Sci J 48: 317-37.

Döll P, Kaspar F, and Lehner B. 2003. A global hydrological model for deriving water availability indicators: model tuning and validation. J Hydrol 270: 105-34.

Downing JA, Prairie JT, Cole JJ, et al. 2006. The global abundance and size distribution of lakes, ponds, and impoundments. Limnol Oceanogr 51: 2388-97.

FAO (Food and Agriculture Organization of the United Nations). 2010. AQUASTAT geo-referenced database on African dams. www.fao.org/nr/water/aquastat/damsafrica/ index.stm. Viewed 23 Mar 2011.

Geoscience Australia. 2004. Dams and water storages 1990. Canberra, Australia: Commonwealth of Australia. www.ga.gov.au. Viewed 23 Mar 2011.

Graf WL. 1999. Dam nation: a geographic census of American dams and their large-scale hydrologic impacts. Water Resour Res 35: 1305-11.

ICOLD (International Commission on Large Dams). 1998-2009. World register of dams. Version updates 1998-2009. Paris, France: ICOLD. www.icold-cigb.net. Viewed 23 Mar 2011.

Lehner B and Döll P. 2004. Development and validation of a global database of lakes, reservoirs and wetlands. J Hydrol 296: $1-22$.

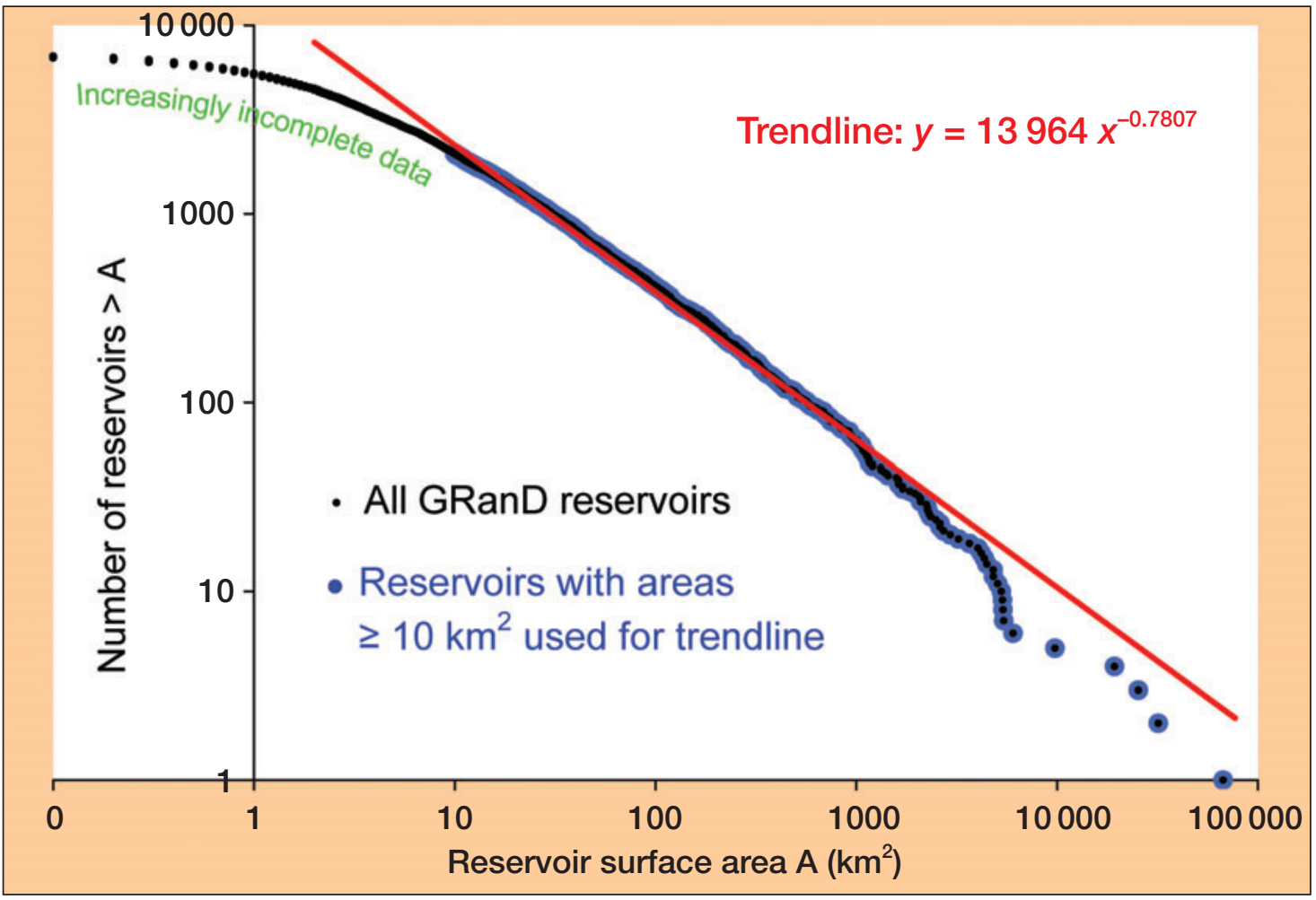

WebFigure 1. Number of reservoirs (y axis) exceeding increasing surface areas ( $x$ axis), based on GRanD. Assuming that the reservoirs larger than $10 \mathrm{~km}^{2}$ surface area are complete records, a trendline can be fitted and extrapolated following a Pareto distribution in order to estimate smaller reservoirs that are not contained in the database. 


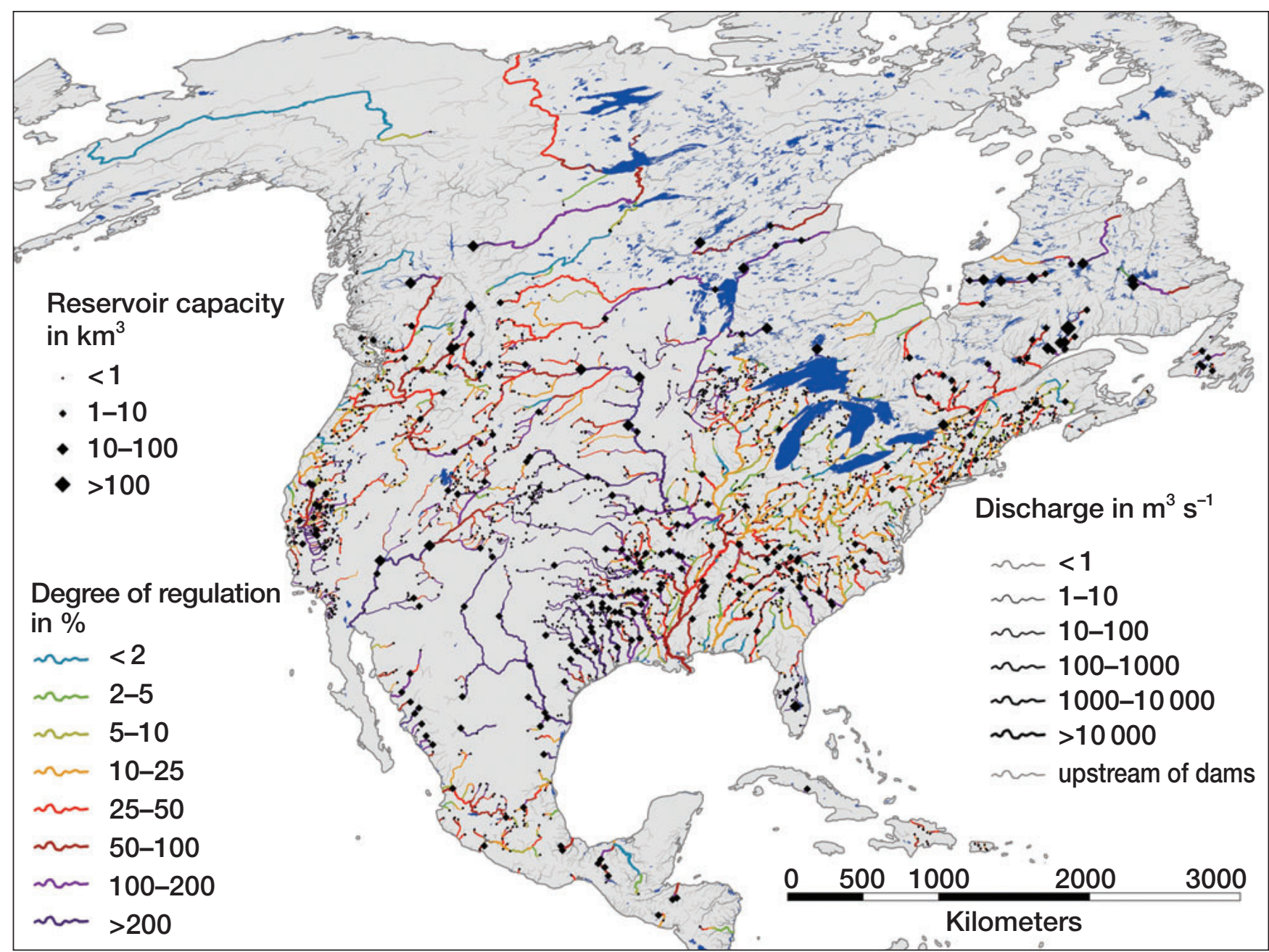

WebFigure 2. Affected river reaches downstream of GRanD reservoirs in North America. 


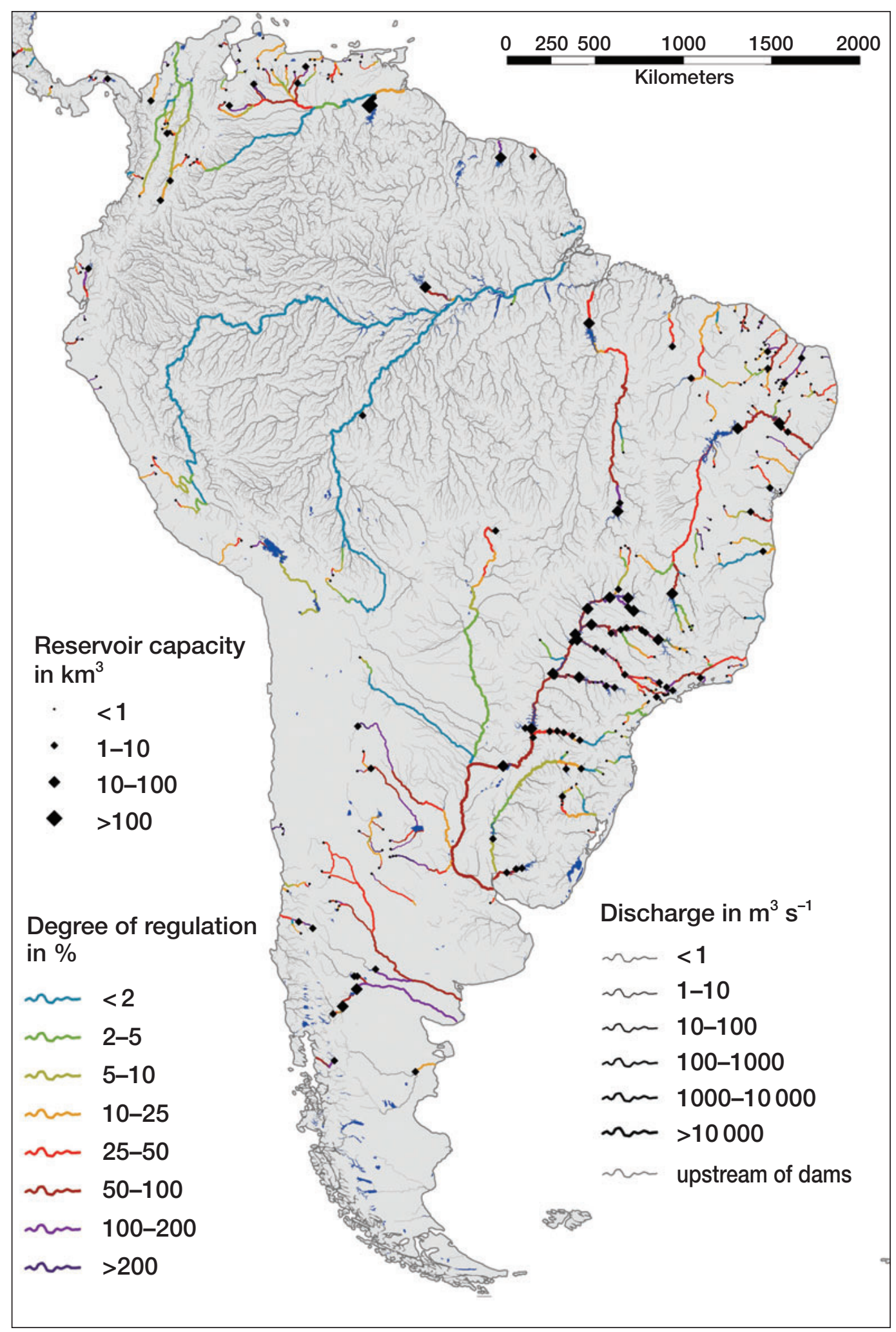

WebFigure 3. Affected river reaches downstream of GRanD reservoirs in South America. 


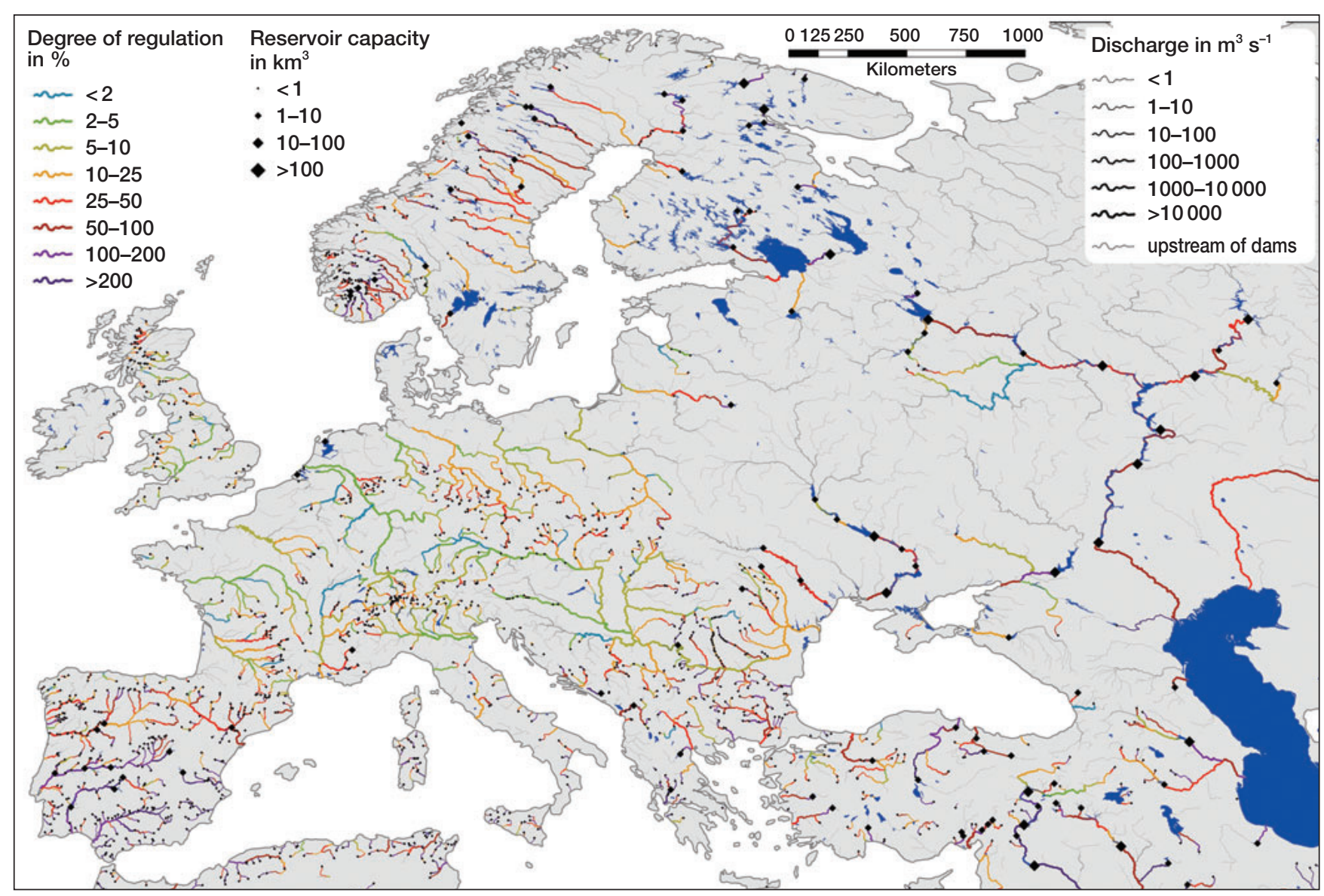

WebFigure 4. Affected river reaches downstream of GRanD reservoirs in Europe. 


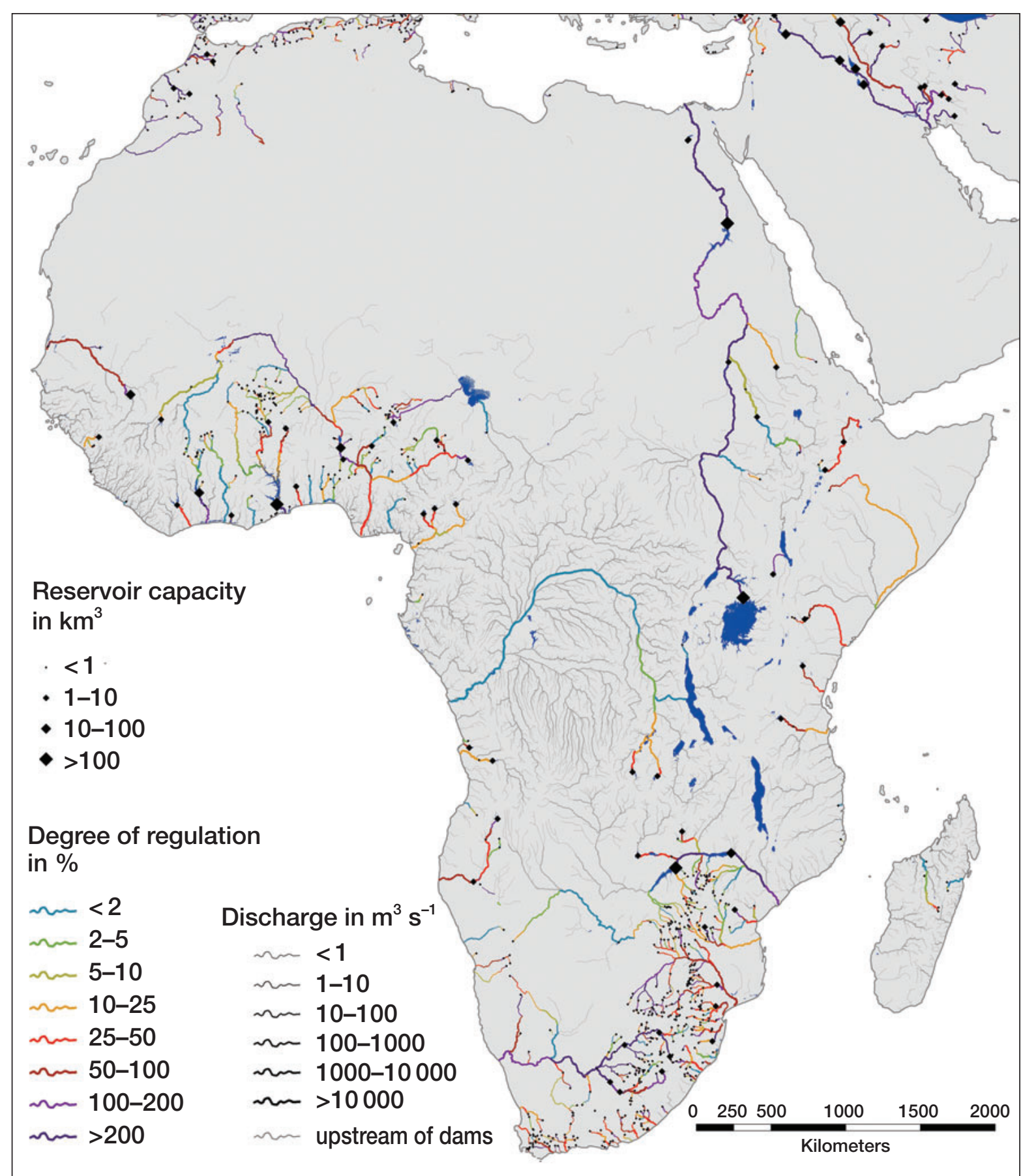

WebFigure 5. Affected river reaches downstream of GRanD reservoirs in Africa. 


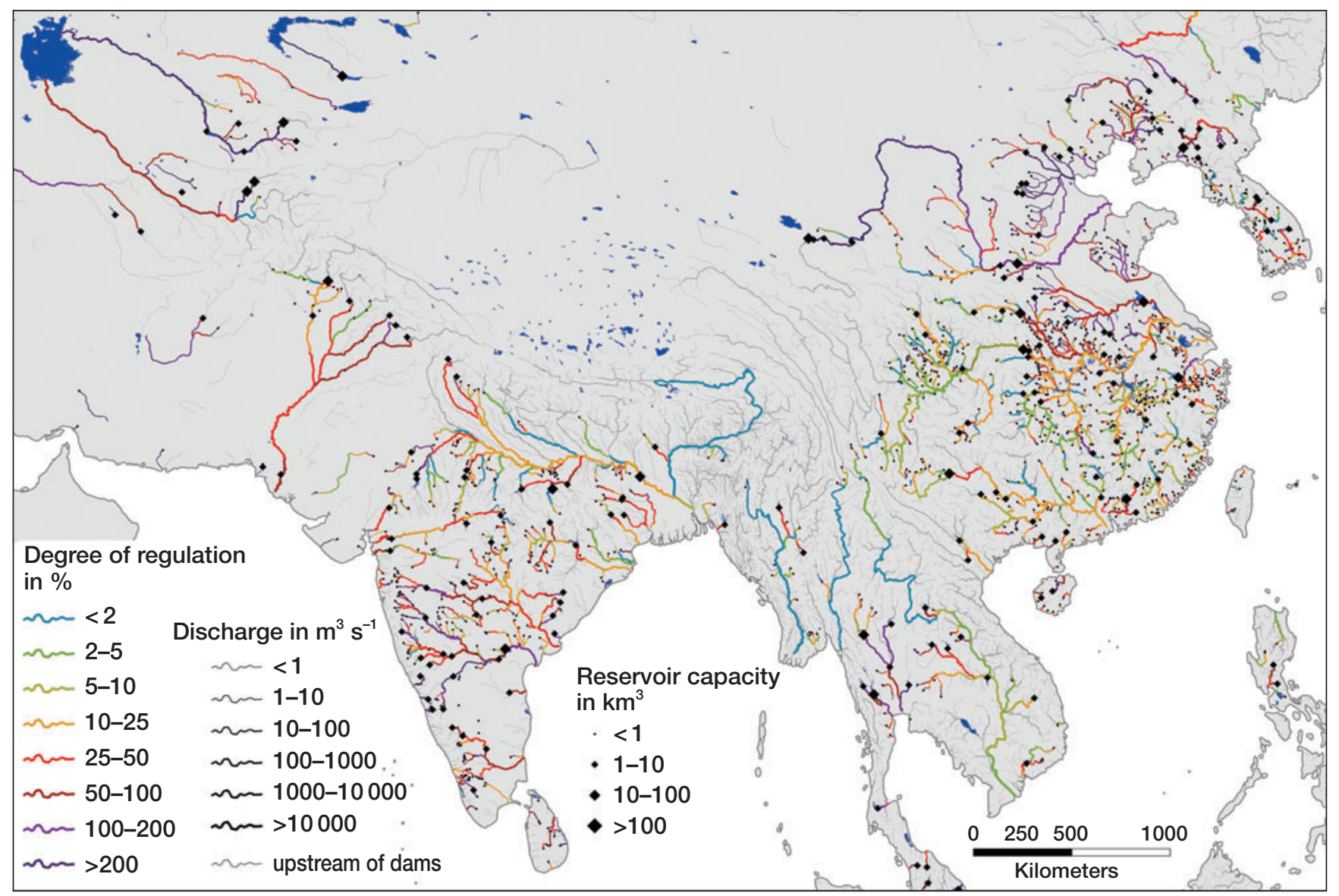

WebFigure 6. Affected river reaches downstream of GRanD reservoirs in southern Asia. 


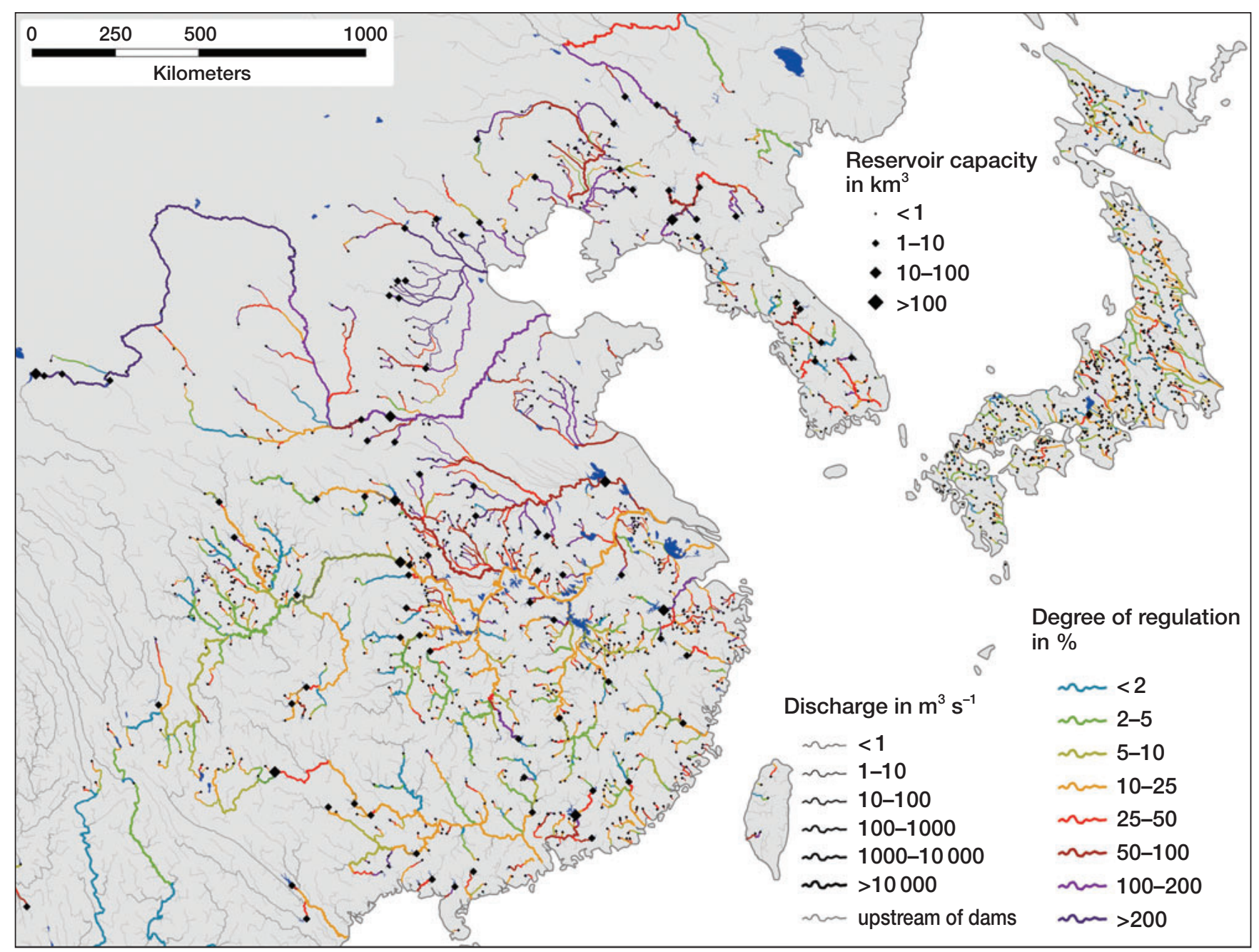

WebFigure 7. Affected river reaches downstream of GRanD reservoirs in Southeast Asia. 


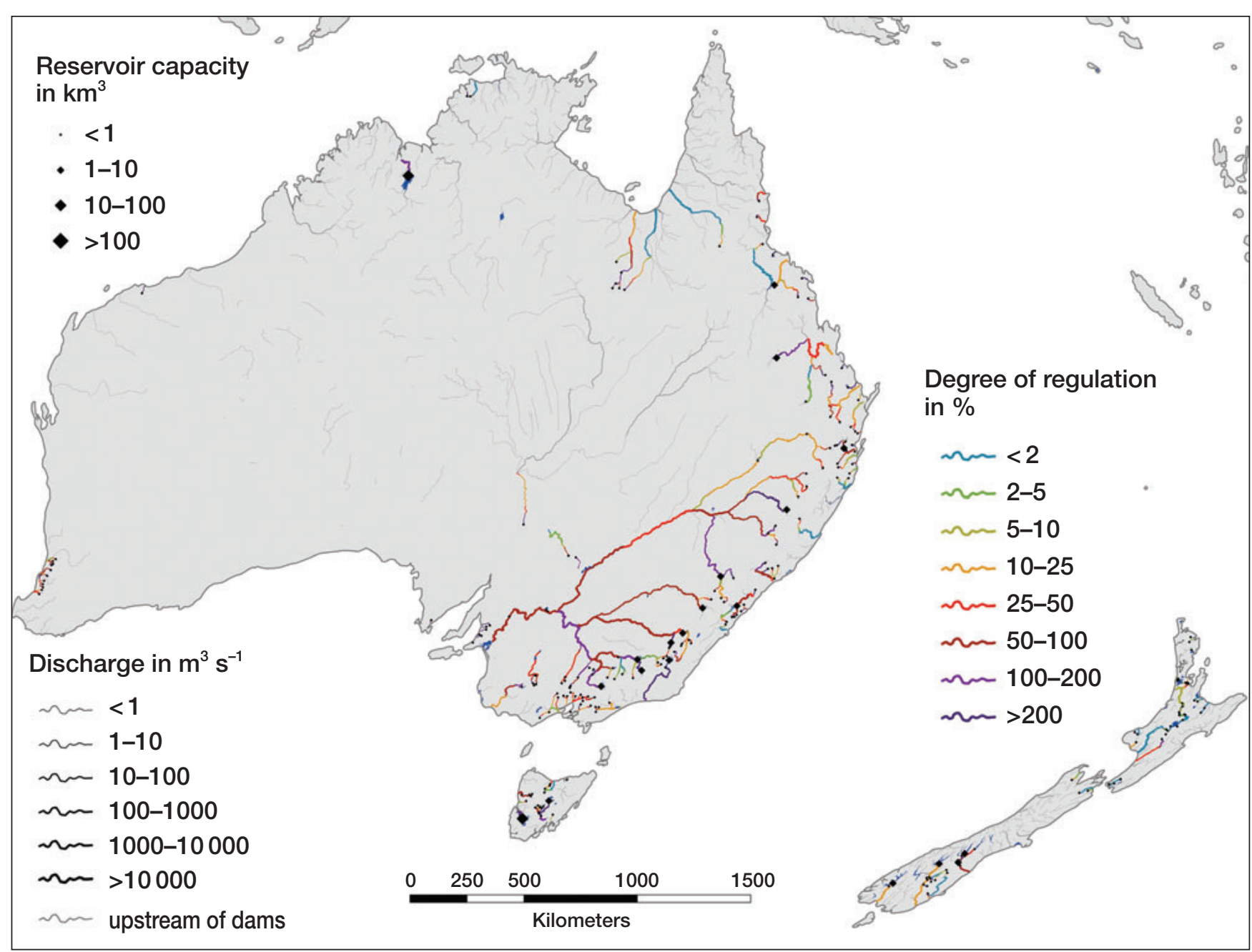

WebFigure 8. Affected river reaches downstream of GRanD reservoirs in Australia and New Zealand. 